International Journal of Educational and Psychological Studies - Vol. 4, No. 1, 2018, pp. 160 - 182

\title{
تقويم مهارات النقد الفني لاى معلمات التربية الفنية وتدريسهن لها في المرحلة المتوسطة في مدينة الرياض
}

\section{غادة بنت عبد الرحمن الدوسري}

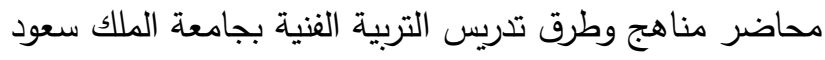

ghaldossari@ksu.edu.sa

\section{عبد الله بن ظافر الثهري}

أستاذ المناهج وطرق التنديس بجامعة الملك سعود

adshehri@ksu.edu.sa

الملخص:

الهذف الرئيسي من هذا البحث هو التحقق من حقيقة تفعيل النقد الفني في المدارس المتوسطة، بالإضافة إلى قياس معلومات

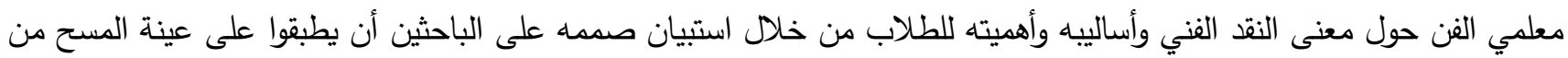
مائتين وثمانية وعشرين المعلمين، بالإضافة إلى بطاقة ملاحظة ليتم تطبيقها على ربع العينة.

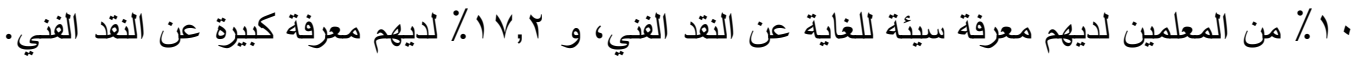
1, 1\% من الأساتذة يمتلكون معلومات قليلة عن معنى النقد الفني، مقارنة بـ 0,1\% ممن يملكون معلومات قليلة عن أساليب النقد الفني، و ع , ا ٪ يمتلكون معلومات قليلة عن أهمية النقد الفني للطالب. لا يشمل المعلمون النقد الفني ضمن أهداف الخطة في تقاريرهم التخطيطية الشهرية أو السنوية. ومن ناحية أخرى ، فإن

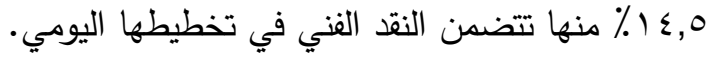

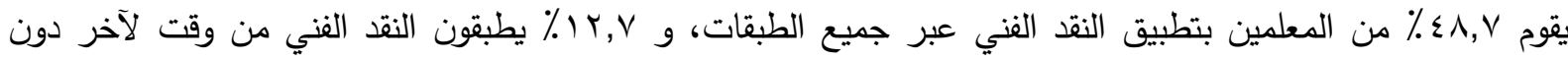
تخطيط العملية ودون أي تفسير لأساليب النقد الفني للطلاب.

توصيات ومقترحات مهمة:

من المهم إعادة صياغة الخطط المعتمدة من قبل وزارة التعليم، وتضمين النقد الفني ضمن الأهداف والوسائل. من المهم تطوير دورات موجهة لمعلمي المدارس المتوسطة، تتعق بالنقد الفني، حيث يتم توضيح تفعيل النقد الفني على الفى لفي

$$
\text { الرغم من الطبقات الخارجية. }
$$

من الضروري تزويد معلمي الفن ببعض المراجع حول النقد الفني من أجل زيادة معرفتهم بالنقد الفني. 
في المدارس القديمة نُظر إلى مادة التربية الفنية كمادة منعزلة عن المواد الأخرى، والغاية الوحيدة منها هي اكتساب التلاميذ

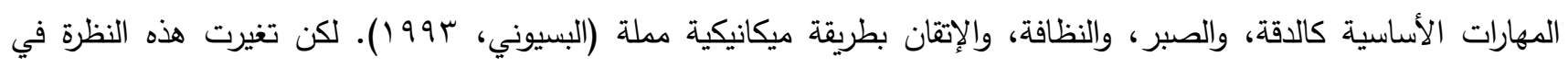
الوقت الحالي بعد أن تبوأت التربية الفنية مكانة كإحدى المواد اللاتي لها دور أساسي في تكوين شخصية التلميذ، وبنائها بناء

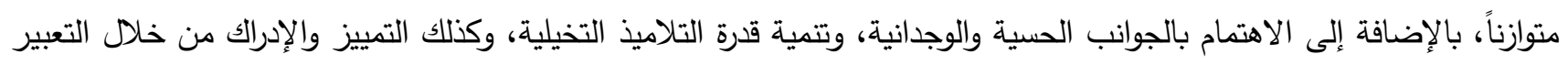

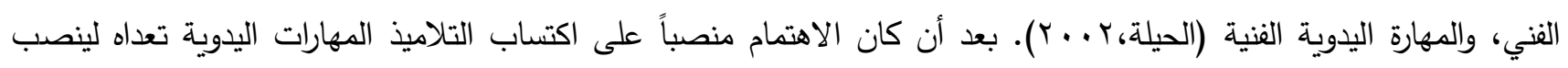

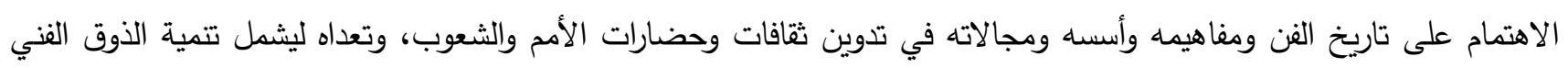
العام وتكوين الشخصية الناقدة المتفهمة لنواحي الجمال، وساعد ذلك على بناء علاقات وثيقة بين التئن التربية ووظيفة الفن والتربية الفنية، وهذه العلاقة لا تتحقق إلا من خلال عمليات التذوق والنقد الفني. فالنقد الفني يعد من أهم العناصر المكونة للثقافة الفنية، وينعكس

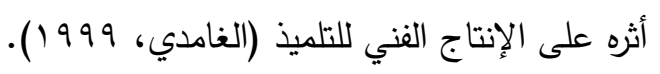
من الملاحظ أن النقد الفني منذ الإعداد للدروس يتم إدخاله بشكل عارض بدون الإنتاء لخطيط مسبق لهذا الإجراء، ولاحظ الباحثان أن هذا الإجراء يتم من خلال تخصيص المعلم لجزء من الحصة له، وهذا التخصيص لا يتم بشكل دائم؛ بل يعتمد على رغبة المعلم والزمن المتاح له، بالإضافة أنه لا يتم تحديد قواعد واضحة للتلميذ يتم النقد على أساسها. لذلك رأى الباحثان أنه لابد من تقويم مهارات النقد الفني لاى معلمات التربية الفية لإنية وأوجه القصور في تدريسهن لها في المرحلة المتوسطة بمدينة الرياض لأن هذه المهارة لها أهمية كبرى في اكتساب التلميذ القدرة على إصدار أحكام جمالية على الأعمال الفنية، لفال

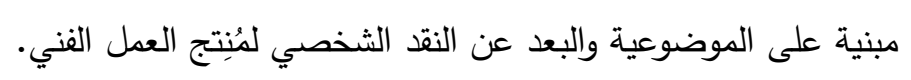
وقد تم استعراض عدد من الدراسات السابقة العربية والأجنبية المتعلقة بالتربية الفنية والنقد الفني وتوصل الباحثان إلى الى مجموعة من النقاط:

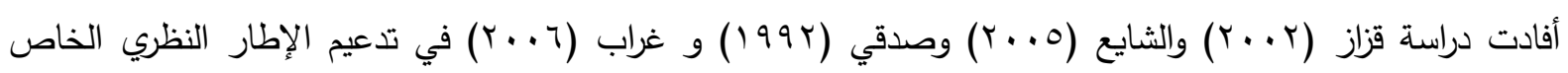

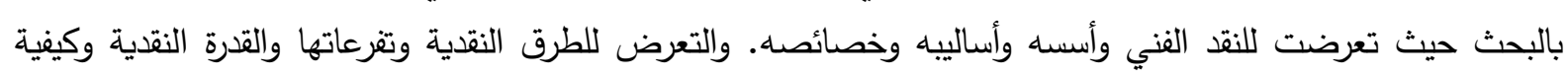
تتميتها وتطويرها وتفعيلها لدى المتعلمين.

أفادت بعض الدراسات من خلال تناول النقد الفني في المرحلة المتوسطة بالبحث والدراسة مثل دراسة الغامدي (1999 (199) .

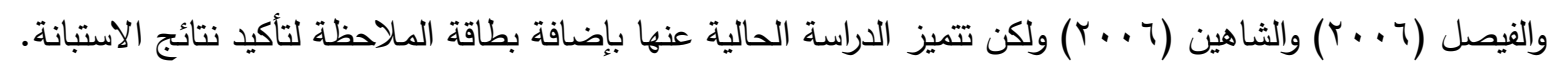
وضحت بعض الدراسات الاستراتيجيات التعليمية والإجراءات التي من الواجب على ولى المعلم التبل التباعها من أجل تفعيل النقد

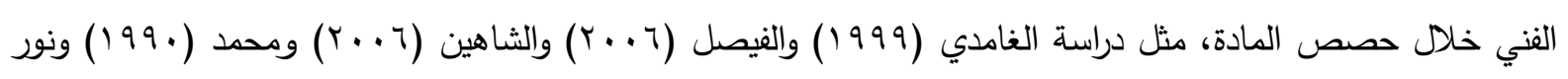

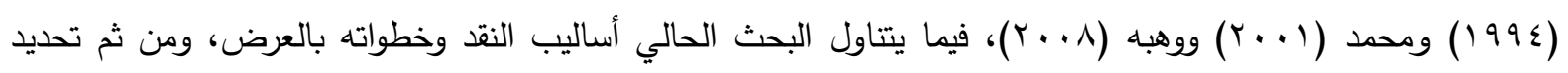
الأساليب الأكثر استخداما في حصص التربية الفنية من قبل معلمات التربية الفنية.

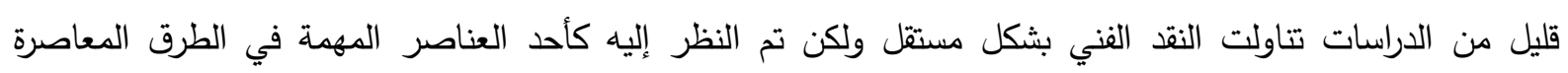

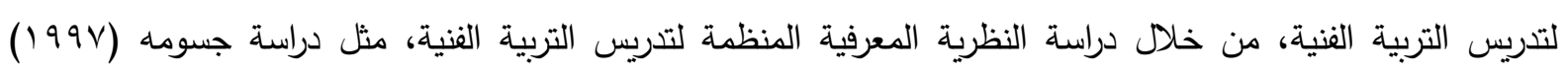

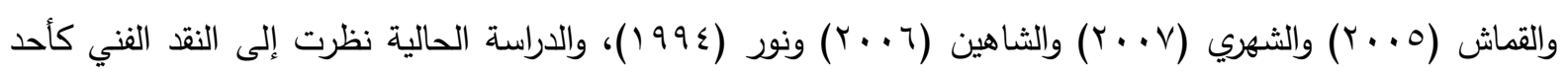
العناصر المهمة في تتمية الثقافة الفنية، ولكن ركزت الاهتمام عليه بالبحث والتحليل والتحقق من مدى تطبيقيه بمعزل عن والثن العناصر الأخرى.

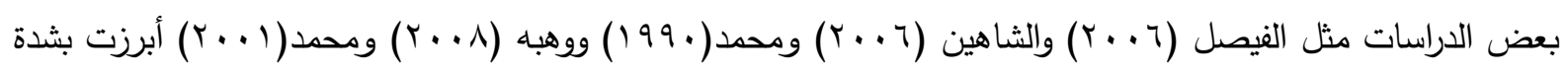

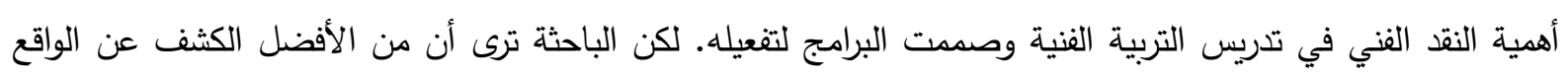
قبل البدء في تصميم البرامج وتطبيقها ومن ثم قياس أثرها. 


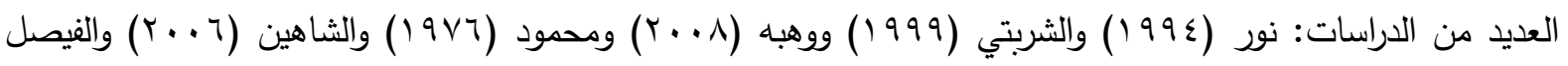

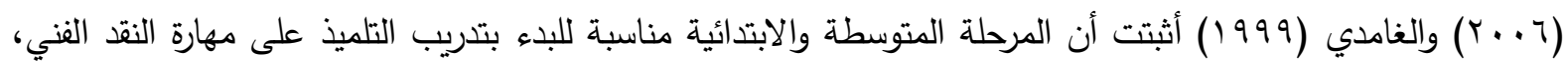

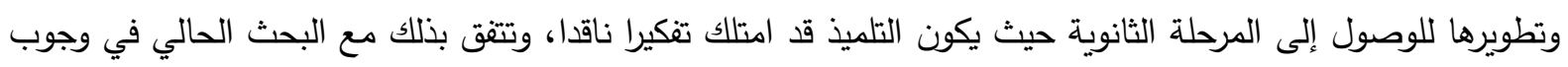
تفعيل النقد الفني منذ المرحلة المتوسطة والتتوع في الأساليب المستخدمة من أجل تتمية قدرة التلميذات النقدية.

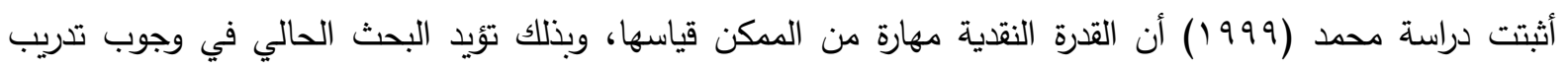
التلميذات على مهارة النقد وقياس تطورهن في ممارستها. من خلال التحليل السابق للدراسات السابقة حاول الباحثان تجميع أكبر قدر من الدراسات التي سوف يتل يتم الاستفادة منها في تصميم أدوات البحث وتطبيقها وفي مناقشة نتائجه.

\section{النقد الفني خلال حصص التربية الفنية:}

التربية الفنية هي عملية تثكيل السلوك الإنساني عن طريق الفن، وتوجد علاقة وثيقة بين وظيفة التربية والفن والتربية الفنية.

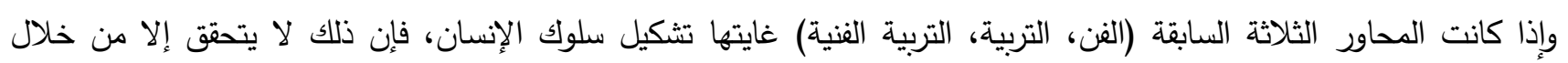
عمليات النقد والتذوق التي تكسب التلميذ المعلومات والمدركات بأشكالها المختلفة المشبعة بخبرة أجيال سابقة حيث يتم فئم تعديل

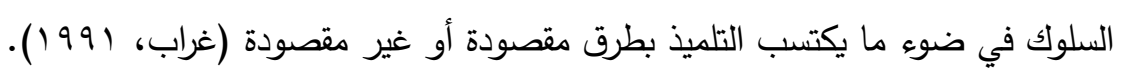

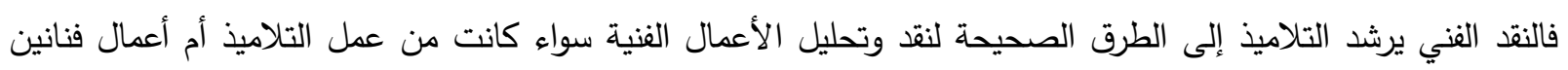
بأسلوب موضوعي والتي تتم من خلال المناقثات في الفصل، وتعليمهم المصطلحات الفنية المتعلقة بالنقد لتوفير ثقافة تذوقيه ونقدية في الوقت نفسه. كما تساعده على أن يطور ثقافته والتي تساعده في المواد الدراسية الأخرى وتطوير مهاراته النفسية واللغوية والعلمية

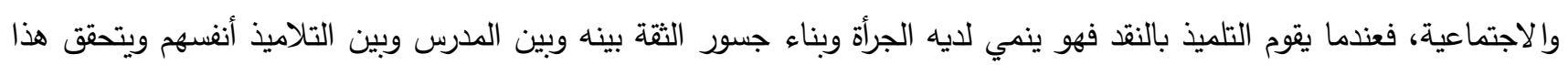

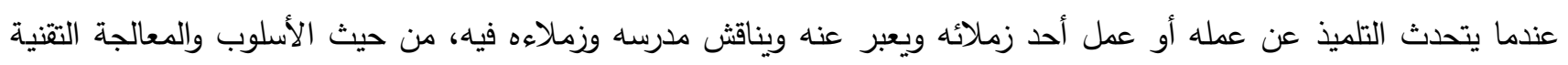

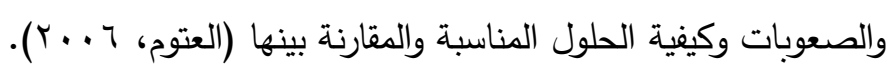

ويعتبر تدريس النقد الفني ضمن التربية الفنية مهما، لما يقدمه من ثقافة فنية يحتاجها التلاميذ في مراحلهم المختلفة والتي

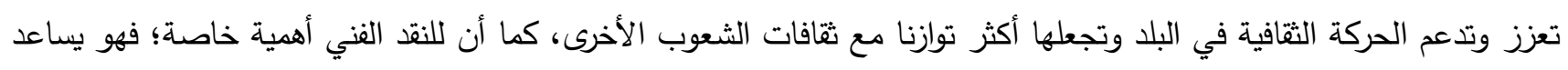

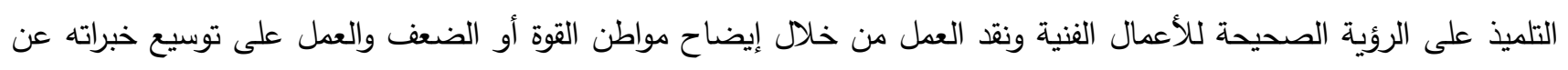

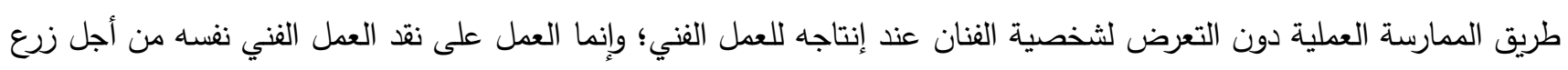
ثقة المتعلم بنفسه وتحفيزه على العمل للوصول إلى درجات ومستويات أفضل من الابتكار (العتوم، V . . Y). تفعيل النقد الفني خلال حصص التربية الفنية:

يستطيع معلم التربية الفنية تفعيل النقد الفني خلال خصص التربية الفنية من خلال عرضه لأعمال فنانين عالميين أو محليين

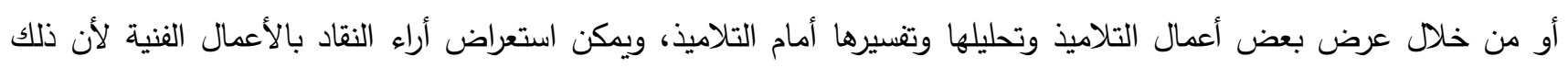
يعتبر عاملا إضافيا لتمكين التلاميذ من القدرة على تفعيل عملية النقد لديهم، ثم يعطي التتلاميذ فرصة المشاركة ونقد أعمالهم الفنية أو أعمال زملائهم. ويجب ألا تكون عملية النقد شخصية- بمعنى أن على المعلم عندما يقوم بنقد أو تقويم العمل الفني الذي أنتجه التلميذ ألا يتعداه إلى شخصية التلميذ وتجريحه، بل تقتصر على معرفة الجوانب الإيجابية والتأكيد عليها والتعرف على مواطن الضعف ومعالجتها، إن عملية النقد يجب أن تكون بناءة وليست هدامة للوصول إلى أعمال ابتكاريه راقية. وتتم هذه العملية على مراحل تجاه العمل الفني تتمثل في إدرالك العمل الفني ووصفه والتعرف على معلى معانيه من خلاد التحليل والتفسير والقيام بعرض وجهات نظر مختلفة حول الأعمال الفنية أو الفن، ودور الناقد (المعلم أو التلميذ) لا يتوقف على ذلى ذلك بل 


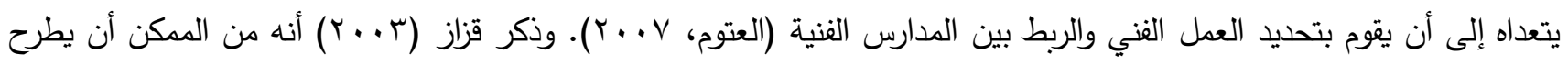

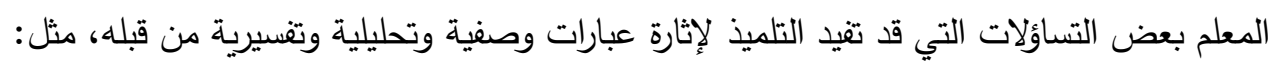

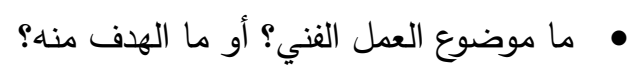

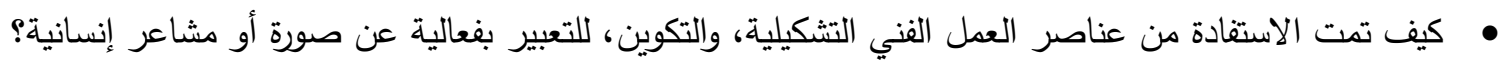

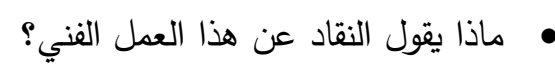

ما الوظيفة التي يمكن أن تكون لعمل فني من هذا النوع في المجتمع؟ هول

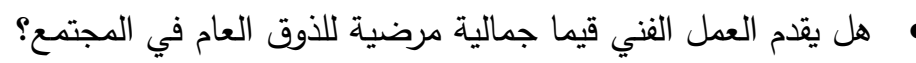

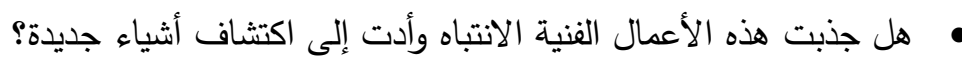

وبهذا سوف يساعد النقد الفني التلاميذ على توصيل أفكارهم بشكل مؤثر ، وسوف يكون للنقد الفني دور في تعزيز المعرفة

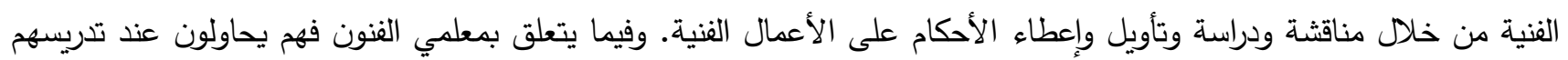
للنقد تقديم إجابات عن الأسئلة التالية:

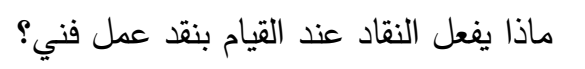

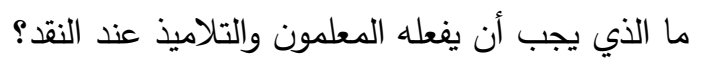

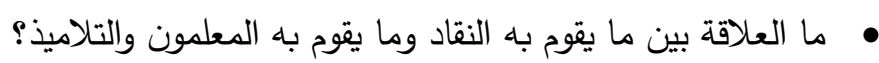

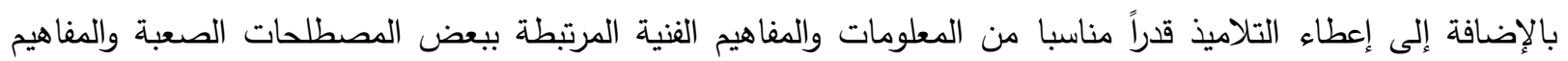

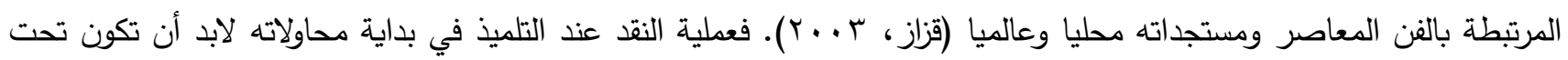

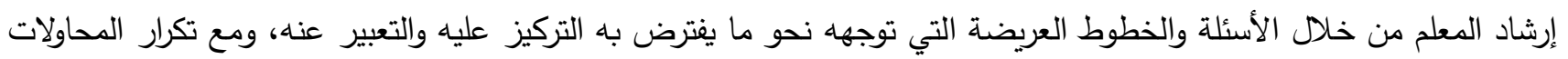
للتلميذ في نقد الأعمال يقل دور المعلم التوجيهي ويبدأ التلميذ في اتخاذ خطوات النقد بدون إرشاد، وبالتالي مع الخبرة والممارسة يصل التلميذ إلى انتهاج أسلوبه الخاص في النقد باستعمال العبارات الفنية المتخصصة.

\section{مشكلة البحث:}

على الرغم من تعدد البحوث والدراسات التي قامت بدراسة وتحليل الأهداف السلوكية (الأهداف المهارية والأهداف المعرفية

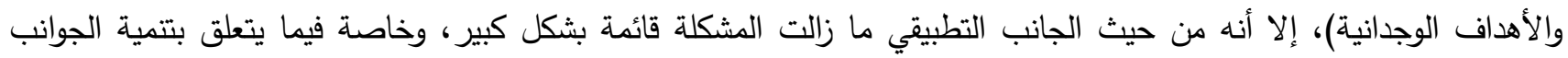
الوجدانية والمعرفية. ذكر الغامدي (999 (19) في دراسته أنه مازال هنالك عدد من معلمي التربية الفنية يركز على الإنتاج الفني

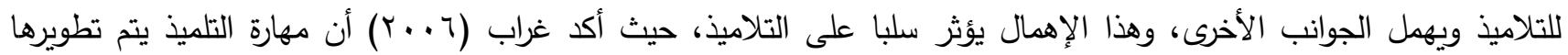

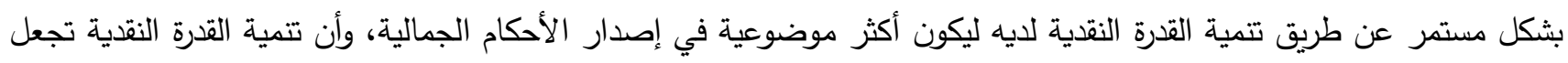
التلميذ قادرا على خلق معايير نقدية خاصة به تتدمج فيها مهارات التفكير النقدي، وأوصى بالاهتمام بتتمية التفكير الناقد من خلال

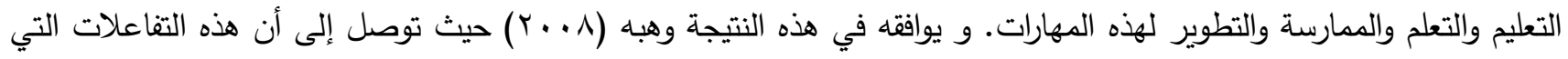
تحدث خلال الحصة بين التلميذ والعمل الفني تكسبهم العديد من المعارف والمفاهيم الفنية، وتساعد على نمو القدرة على التعبير والثقافة البصرية. مما سبق تتحدد مشكلة البحث في توضيح مدى اهتمام وتفعيل معلمات التربية الفنية لعنصر النقد الفني في حصص المادة، بكونه أحد العناصر الأساسية المكونة للثقافة الفنية، بالإضافة إلى التساؤل حول إلمام معلمات التربية الفنية بأهمية ومعنى النقد

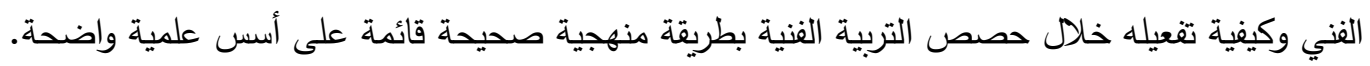

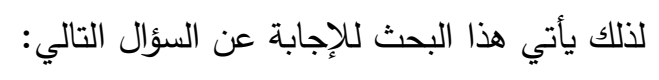
ما مستوى تدريس معلمات التربية الفنية بالمرحلة المتوسطة في مدينة الرياض لمهارات النقد الفني؟ 


$$
\text { يسعى البحث إلى تحقيق الأهداف التالية: }
$$

ا. . التعرف على الطريقة التي تتتهجها معلمة التربية الفنية من أجل تفعيل النقد الفني خلال حصص المادة. r. أ. التعرف على واقع تفعيل النقد الفني خلال حصص التربية الفنية بالمرحلة المتوسطة في مدينة الرياض. r. التعرف على مدى إدراك معلمات التربية الفنية بالمرحلة المتوسطة في مدينة الرياض لمعنى وأهمية النقد الفني.

ع. التعرف على مدى معرفة معلمات التربية الفنية بالمرحلة المتوسطة في مدينة الرياض بأساليب النقد الفني.

\section{أهمية البحث:}

$$
\text { تتركز أهمية البحث على ما يلي: }
$$

ا. . ندرة البحوث التي اهتمت بجانب النقد الفني ومدى تفعيله خلال حصص التربية الفنية خصوصا في المملكة

$$
\text { العربية السعودية. }
$$

r. ب المساهمة في إيضاح أهمية النقد الفني باعتباره أحد العناصر المهمة لتكوين الثقافة الفنية. r. المساهمة في توضيح أهمية النقد للأعمال الفنية وحث المعلمات على تفعيله خلال حصص احص التربية الفنية.

أسئلة البحث:

$$
\text { يسعى البحث الحالي إلى الإجابة عن السؤال الرئيس التالي: }
$$

\section{ما مستوى تدريس معلمات التربية الفنية بالمرحلة المتوسطة في مدينة الرياض لمهارات النقد الفني؟ لإئي}

ويتقرع من هذا السؤال الرئيس الأسئلة الفرعية التالية:

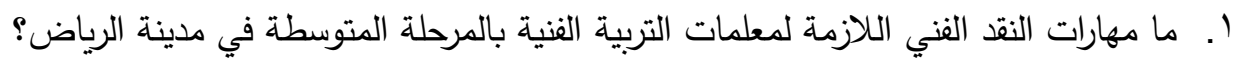

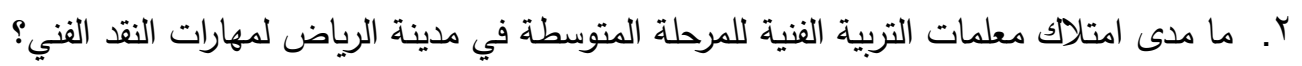

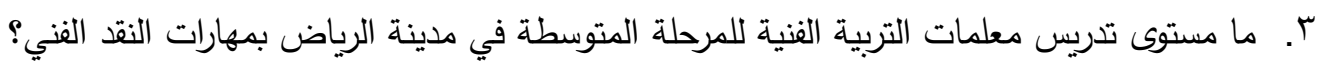

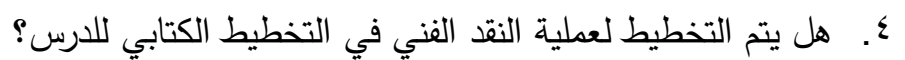

0. هل يتم تفعيل النقد الفني خلال حصص التربية الفنية بالمرحلة المتوسطة في مدينة الرياض؟

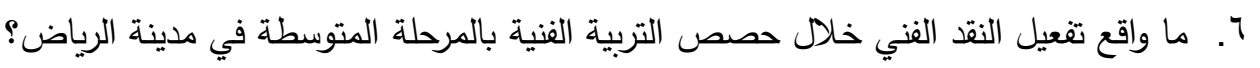

V. هل تتم الاستعانة بمراجع خاصة بالنقد الفني عند الإعداد لدروس التربية الفنية؟ باله

حدود البحث:

يقتصر هذا البحث على معرفة مدى تفعيل معلمات التربية الفنية للنقد الفني بالمرحلة المتوسطة في التعليم العام، باعتبار أن المرحلة المتوسطة مرحلة انتقال من الطفولة إلى المراهقة. اقتصر البحث في الحدود المكانية على مدينة الرياض في المملكة العربية السعودية.

مصطلحات البحث:

• النقد الفني:

المعنى الاصطلاحي: هو أحد عناصر التربية الفنية المعاصرة، يهتم بالحديث أو الكتابة عن الأعمال الفنية، من خلال وصفها

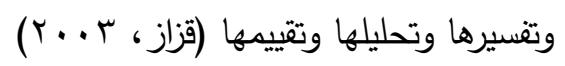


المعنى الإجرائي: هي عملية مخطط لها مسبقا، ومدرجة ضمن الأهداف السلوكية الإجرائية للدرس، يقوم بها التلميذ بمساعدة المعلم خلا حصص التربية الفنية، بحيث يُقيّم عمله الفني وأعمال زملائه بناء على أسس ومعايير فنية، وتتسم هذه الأهية العملية بالموضوعية والبعد عن ذاتية التلميذ.

\section{• \\ المعنى الاصطلاحي: هي عملية تشكيل السلوك الإنساني عن طريق الفن (غراب، (991).}

والتربية الفنية هي التعبير عن فكرة أو موضوع بواسطة وسائل التنفيذ العديدة وهي التي تمتع العين، وتوقظ العاطفة، وتئ، وترتقي

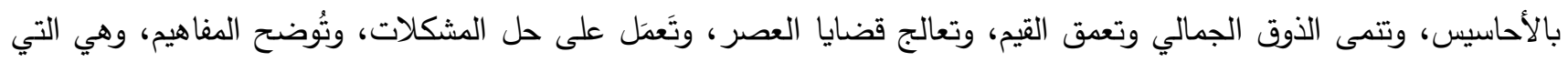

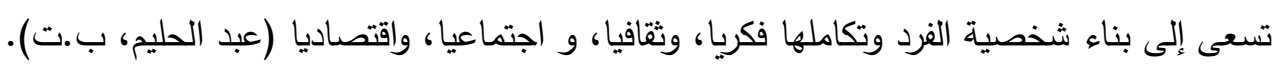
المعنى الإجرائي: هي مادة من ضمن المواد الدراسية في المرحلة المتوسطة وتعني تدريس الرسم والتلوين والأشغال اليدوية. وهي والتي عملية إكساب التلاميذ القيم والاتجاهات الإيجابية بما يُحدث التطور في الفرد من خلاد تتمية الإحساس بالجمال المحيط بهم عند

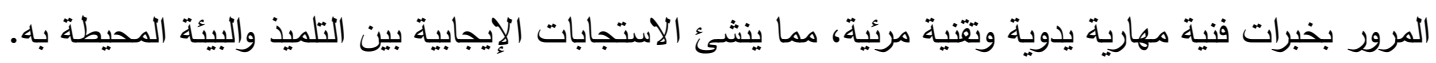

منهج البحث:

إن المنهج المتبع في هذا البحث هو المنهج الوصفي التحليلي، الذي يصف الظاهرة ويجمع حولها أكبر قد من المعلومات وبعبر عنها كميا وكيفيا، "ولا يقف عند حدود جمع المعلومات عن الظاهرة وإنما يذهب أبعد من ذلك فيحلل ويفسر ويقارن ويقيّم أملاً في التوصل إلى تعميمات يزيد بها رصيد المعارف عن تلك الظاهرة" (الزوبعي والغنام، ع \9 ()).

\section{مجتمع البحث:}

يشمل مجتمع البحث جميع معلمات التربية الفنية للمرحلة المتوسطة في مدينة الرياض ضمن مدارس التعليم الحكومي

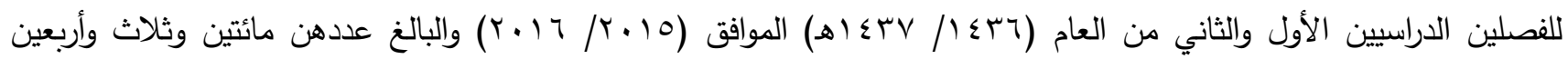
معلمة (r\&) وقد حصل الباحثان على الإحصائية من مركز المعلومات والدعم الفني في إدارة تعليم الرياض.

عينة البحث:

قام الباحثان باستخدام طريقة الحصر الثامل لمجتمع البحث حيث يرى العساف "أن الأصل في البحوث العلمية أن تجرى

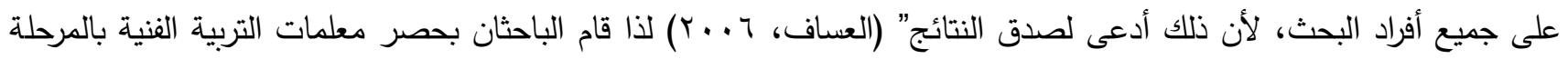
المتوسطة بمدينة الرياض من خلال الرجوع إلى مركز المعلومات والدعم الفني في إدارة تعليم الرياض وكان عدد المعلمات الكلي

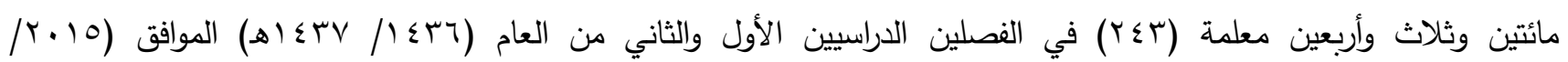

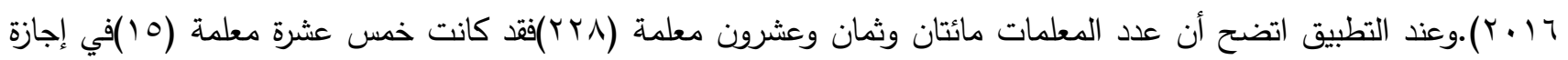

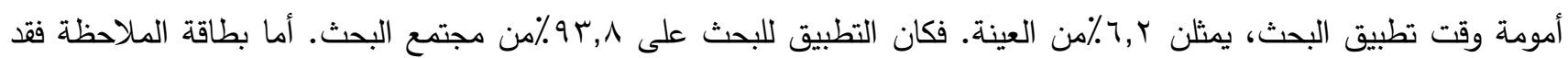
تم تطبيقها على عينة عشوائية من عينة البحث تمثل هب٪من العينة، ويبلغ عددها اثنتين وستين (rآ) معلمة. أدوات البحث:

قام الباحثان باستخدام الاستبانة من أجل جمع المعلومات المتعلقة بموضوع البحث، كما قاما باستخدام بطاقة الملاحظة كأداة

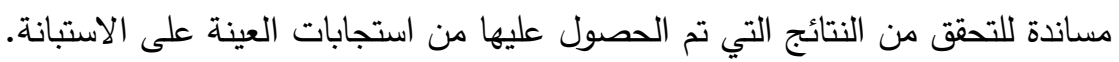

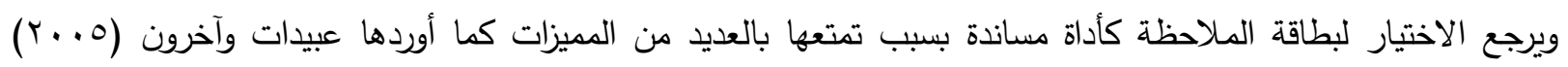

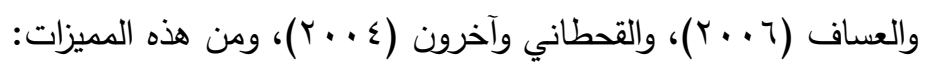


أن بطاقة الملاحظة مناسبة لموضوع البحث من أجل تأكيد استجابات العينة على الاستبانة، ومدى مقاربتها لما يحدث

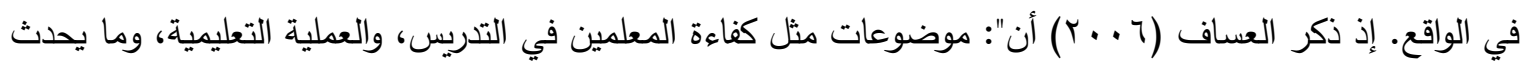
في غرفة الصف، هي موضوعات يمكن بحثها وجمع المعلومات عنها بواسطة الاستبانة أو المقابلة، ولكن نتائج

البحث سوف تكون أقل دقة وأبعد عن وصف الواقع وتشخيصه مما لو تم بحثها بواسطة الملاحظة."

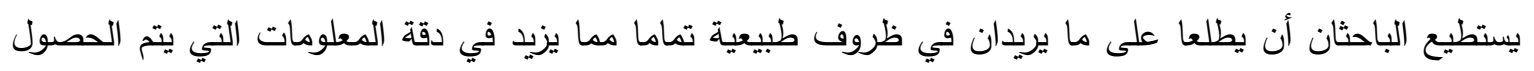
عليها من خلال هذه الطريقة. الملاحظة تسمح وتضمن للباحثين الحصول على المعلومات التي تمكن من الإجابة على أسئلة البحث.

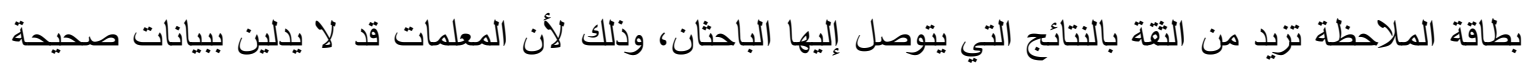
من خلال الاستبانة. بالرجوع إلى الدراسات السابقة، والمراجع ذات العلاقة المباشرة في المجال تم التوصل إلى أن الطريقة الأمثل لقياس معلومات المعلمات عن النقد الفني تتمثل في أسئلة مغلقة تُمثل سلوكيات يتم تطبيقها خلال حصص التصات التربية الفنية بمشاركة التلميذات من أجل تطبيق النقد الفني بشكل مثالي. توصل الباحثان إلى تصميم أداة بحث تحتوي على إحدى وخمسين عبارة

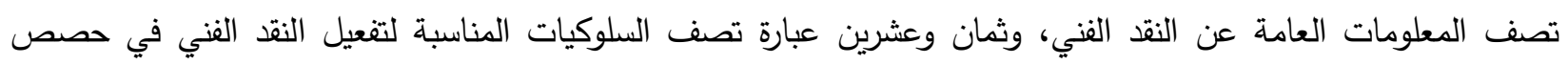
التربية الفنية. وبعد عرضها على محكمين من ذوي الاختصاص في المجال تم ادخال بعض التعديلات على الاستبانة وهي

$$
\text { كالتالي: }
$$$$
\text { حذف عدد من العبارات لتقليل عدد العبارات في الاستبيان. }
$$

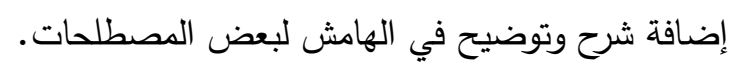

اشتمل الاستبيان بصورته النهائية على المحاور التالية:

ا. الدحور الأول يشمل البيانات الأولية: وهي عبارة عن مجموعة من المتغيرات ذات الأهمية الكبيرة في التعرف على خصائص العينة والوقوف على مدى تأثيرها على نتائج البحث. ومن هذا المنطلق تم تحديد المتغيرات

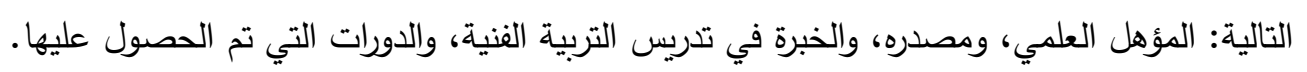
r. المحور الثاني يشمل ثمان وعشرين عبارة في ثلاثة أجزاء لتحديد مدى صحة هذه العبارات. الجزء الأول يقيس

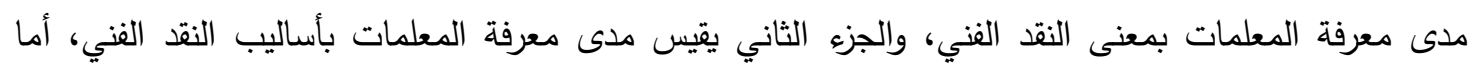
الجزء الثالث فيقيس مدى إدراك معلمات التربية الفنية لأهمية النقد الفني للتلميذة.

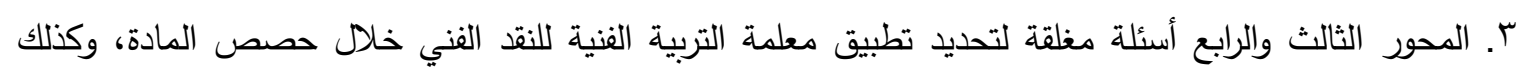
تدوينه في التخطيط الكتابي للدرس، وبناء على الإجابة عن هذا المحورين تنتقل المعلمة للمحور الخامس أو

$$
\text { تتوقف عند هذين المحورين. }
$$

عـ المحور الخامس عبارة عن ثلاث عثرة عبارة لقياس واقع معلمة التربية الفنية عند تطبيق النقد الفني في حصص المادة. وسيستجيب لهذين المحورين فقط المعلمات اللاتي أجبن بأنهن يطبقن النقد الفني في المحورين الثالث

$$
\text { والرابع فقط. }
$$

أما بطاقة الملاحظة فالهدف منها التحقق من مدى مقاربة نتائج الاستبانة للواقع وبذلك سوف تثمل المحاور التالية:

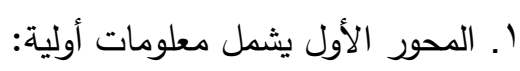

• معلومات متعلقة بالمعلمة: الاسم، والمؤهل، ومصدر المؤهل، والخبرة في تدريس التربية الفنية. • معلومات متعلقة بالملاحظة: مكان الملاحظة، زمن الملاحظة، عنوان الدرس. 
r. المحور الثاني يتعلق بالحصة الدراسية: ويشمل عدد من السلوكيات التي قامت بها المعلمة خلال الحصة الدراسية لتفعيل النقد الفني.

r. المحور الثالث يتعلق بكراسة تحضير الدروس: يتحقق هذا المحور من التخطيط المسبق لتفعيل النقد الفني خلال

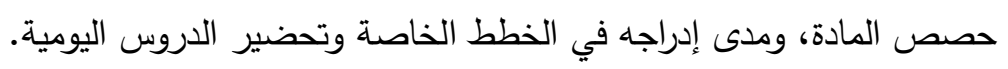

\section{موثوقية أدوات البحث:}

يتم التأكد من موثوقية أدوات البحث عن طريق قياس كُل من الصدق والثبات. وفيما يلي تقصيل ذلك:

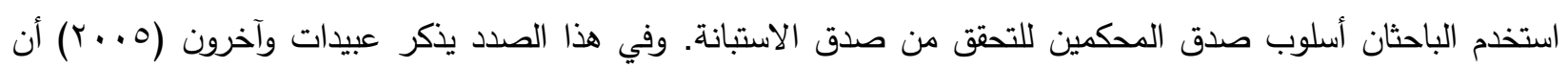

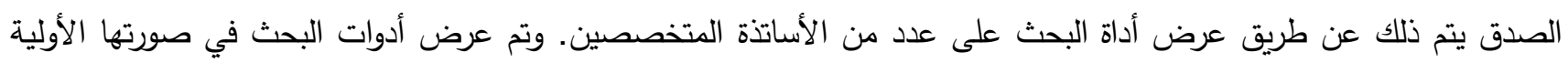

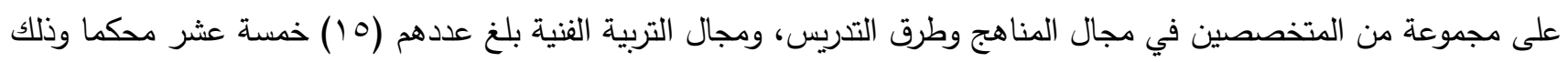
من أجل إبداء الرأي، والتأكد من أن العبارات صادقة في قياس ما وضعت له، وتقدير درجة وضوحها، ومناسبتها لتحقيق أهداف

قام الباحثان بالاستعانة بمركز البحوث في كلية التربية من أجل تطبيق اختبار ألفا كرونباخ على الاستبيان والذي تم تطبيقه

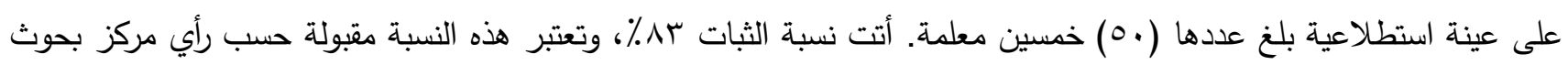
جامعة الملك سعود. أما فيما يتعلق ببطاقة الملاحظة فقد تم تطبيق اتفاق الملاحظين. وتم ذلك كالتالي: • بالتسيق مع أحد الزميلات تم الحضور لعدد (ع) أربع معلمات، وجلوس الملاحظين في مكان في الفصل يتيح لهم رؤية

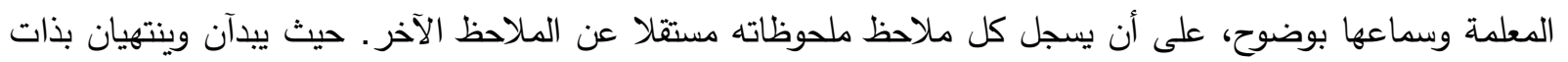
الوقت، وباستخدام نفس الرموز والعلامات. • يتم بعد ذلك حساب معامل الاتفاق بطريقة هولستي (Holsti) التي أوردها طعيمه (ع . . ب) حسب المعادلة التالية:

\begin{tabular}{|lll|}
\hline & $(\mathrm{C})^{r}$ & $=\mathrm{R}$ \\
\hline $\mathrm{C}^{\prime}+\mathrm{Cr}^{r}$ & \\
\hline
\end{tabular}

حيث R= معامل الثبات، و C1+C2 = عدد الفئات التي يتفق عليها الملاحظان، وC رمز للفئة.

\begin{tabular}{|c|c|c|c|c|}
\hline qะV.. & $=$ & $\mu_{\Lambda} \div \mu^{\prime}$ & $=$ & $r(11) \div 19+19$ \\
\hline$q \leq \vee .0$ & $=$ & $r \Lambda \div \mu^{\prime}$ & $=$ & $r(11) \div 19+19$ \\
\hline $1 \cdots$ & $=$ & $\mu_{\Lambda} \div r_{\Lambda}$ & $=$ & $r(19) \div 19+19$ \\
\hline$\cdot, 9$. & $=$ & $\mu \wedge \div \Gamma \varepsilon$ & $=$ & $r(1 V) \div 19+19$ \\
\hline
\end{tabular}

وبذلك يكون الثبات الكلي للأداة:

$9 \leqslant, \wedge 0=\quad \varepsilon \div r \vee q, \varepsilon=9 \cdot+q \varepsilon, v+q \varepsilon, v+1 \ldots$

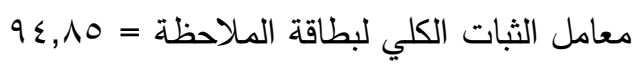


تم استخدام عدد من المعاملات الإحصائية في معالجة بيانات البحث، وهي على النحو النحو التالي: التكرارات والنسب المئوية.

معامل ألفا كرونباخ للتأكد من ثبات الاستبانة ومعادلة هولستي للتأكد من ثبات بطاقة الملاحظة.

\section{عرض ومناقثة نتائج الاستبيان:}

أولاً: سيتم عرض المعلومات الشخصية في الاستبانة والذي يغطي البيانات الثخصية للعينة، فقد اشتمل البحث على مئتين وثلاث

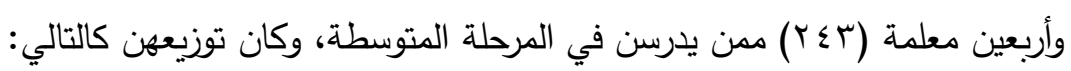

توزيع العينة بناء على المؤهل:

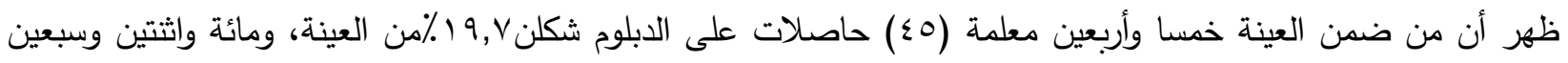

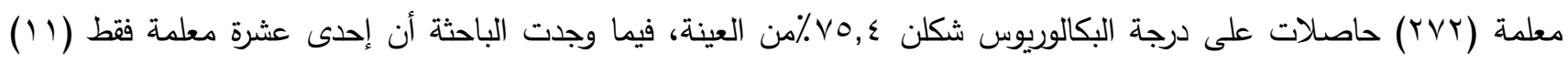

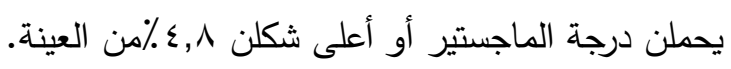
توزيع العينة حسب مصدر المؤهل:

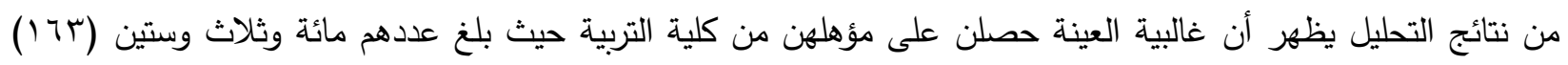

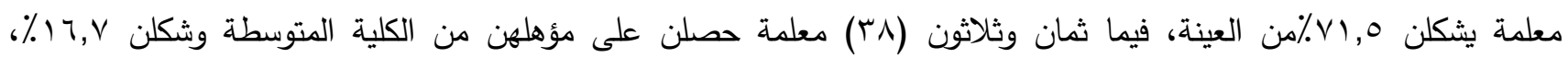

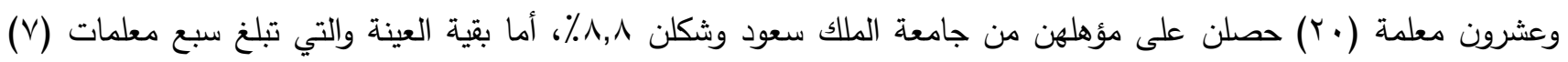

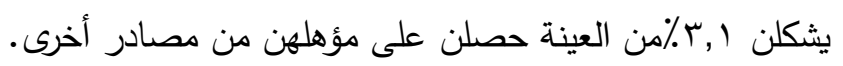
توزيع العينة حسب التخصص: فيما يتعلق بتوزيع أفراد العينة حسب التخصص؛ كان مائة وتسع وسبعون معلمة (V9 V ) متخصصات في التربية الفنية وشكلن

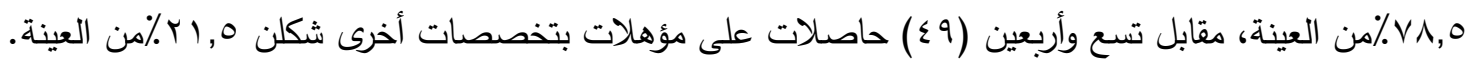

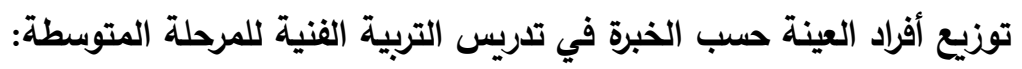

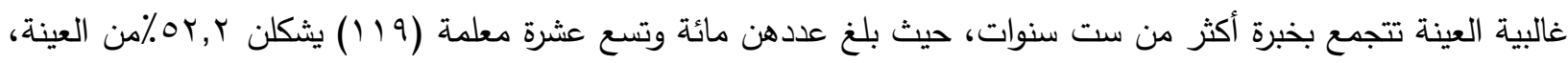

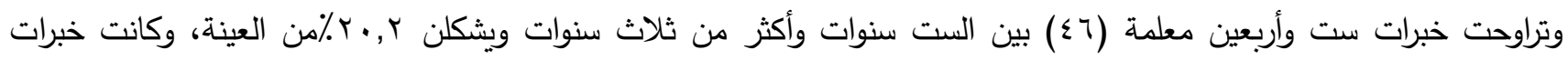

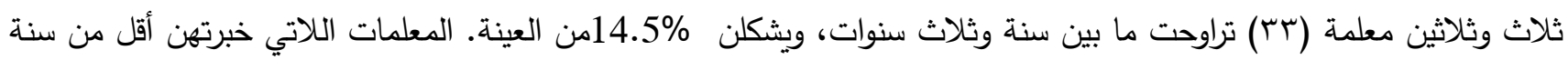

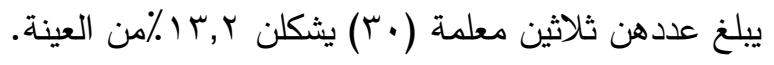

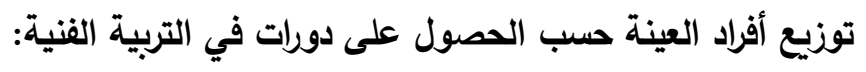
اختص هذا البند بحضور الدورات الخاصة بالتربية الفنية ومهارات تدريسها، واتضح من ذلك أن مائة وثماني عشرة معلمة فئهة

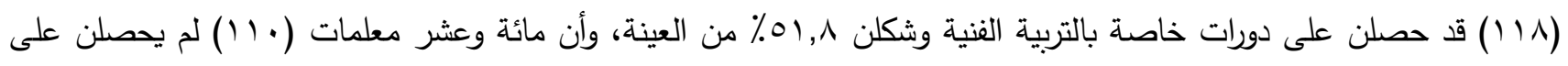

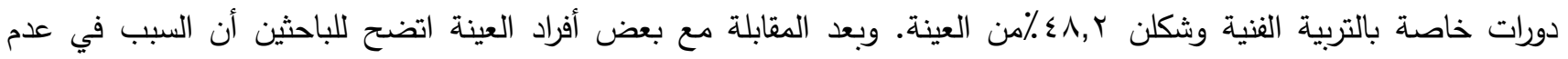

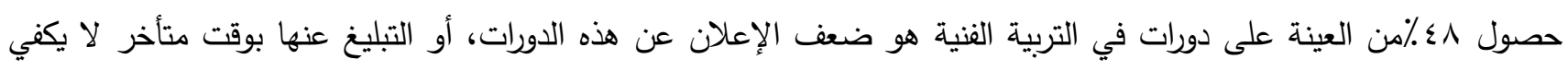

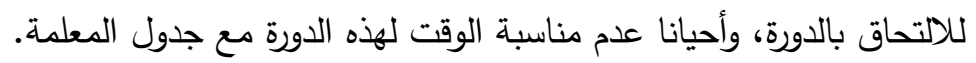
ثانياً: مناقثة الدحور الأول والذي شكل اختبار لقياس معلومات معلمات التربية الفنية في النقد الفني، وقد اشتمل على ثلاثة أقسام :

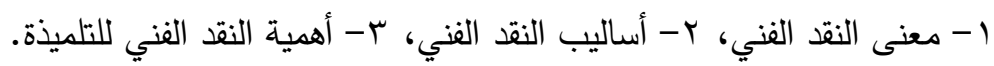
ويجيب هذا المحور على بعض أسئلة البحث التالية:

ا. ـ ما مهارات النقد الفني اللازمة لمعلمات التربية الفنية بالمرحلة المتوسطة في مدينة الرياض؟

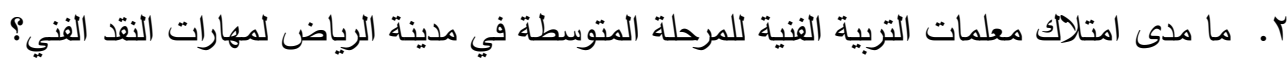


r. ما مستوى تدريس معلمات التربية الفنية للمرحلة المتوسطة في مدينة الرياض بمهارات النقد الفني؟ والجدول رقم (1) يوضح استجابات العينة على هذا المحور:

جدول ( ) : يوضح استجابات العينة على قياس معلومات المعلمة في النقد الفني

\begin{tabular}{|c|c|c|c|c|c|}
\hline$\%$ & أخطاؤ & $\%$ & أصابوا في مند الإجابة & 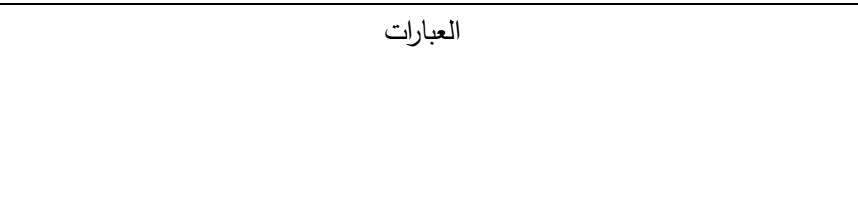 & s \\
\hline \multicolumn{6}{|c|}{ 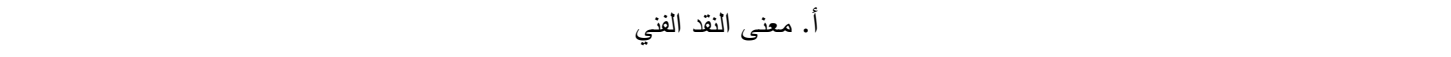 } \\
\hline rt, & or & $\vee \wedge, \wedge$ & ivo & التفكير الناقد مهارة يمكن تتميتها & 1 \\
\hline 94,0 & r) & $\vee, 0$ & iv & وصف العمل الفني لا يعتبر من النقد الفني. & r \\
\hline$r v, r$ & 10 & $T$ T, V & $1 \leqslant r$ & زالنقد الفني خلال حصة التربية الفنية هو تحدث التلميذات عن أعمالهن الفنية أو أعمال & r \\
\hline 19,1 & $\leq 7$ & $\Lambda \cdot, r$ & lat & النقد الفني هو منح العمل الفني التقدير المناسب. & $\varepsilon$ \\
\hline \multicolumn{6}{|c|}{ 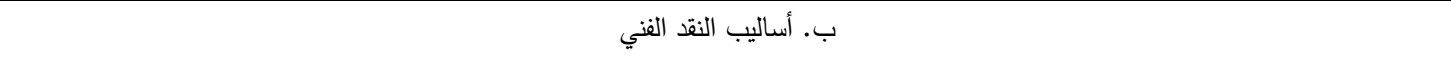 } \\
\hline די & Ar & $T \varepsilon$ & $1 \leq 7$ & تحدث التلميذات عن أعمالهن الفنية من أحد أساليب النقد الفني. & 1 \\
\hline rq & 77 & (1) & $17 r$ & من أساليب النقد الفني التحدث عن العمل الفني وخاماته والأدوات المستخدمة. & r \\
\hline $9 . \wedge 7$ & ros & $1 r, 1$ & r. & من أساليب النقد الفني التحدث عن المشاعر التي يثيرها العمل الفني. & r \\
\hline$r \mathrm{r}, \mathrm{V}$ & $0 \varepsilon$ & $\vee \neg, r$ & $1 v \leq$ & لا يهم إدراك الهدف من العمل الفني قبل نقده. & $\varepsilon$ \\
\hline$\wedge, \varepsilon$ & r. & 91,7 & $r \cdot \wedge$ & عند نقد الأعمال الفنية يتم تمييز العناصر الأساسية والثانوية في العمل الفني. & $\circ$ \\
\hline $1 \leqslant, 0$ & rr & 10,0 & 190 & من الممكن أن يشارك أكثر من تلميذة (مجموعة) من أجل نقد أحد الأعمال الفنية. & 7 \\
\hline \multicolumn{6}{|c|}{ ج. أهمية النقد الفني للتلميذة } \\
\hline$\Lambda, r$ & 19 & $91, \mathrm{~V}$ & $r \cdot 9$ & النقد الفني يساعد على زرع ثقة التلميذة بنفسها وعملها. & 1 \\
\hline $1 \cdot, 0$ & $r \varepsilon$ & 19,0 & $r \cdot \varepsilon$ & النقد الفني يساعد التلميذة على الوصول إلى الابتكار في أعمالها الفنية. & r \\
\hline 10,1 & 190 & $1 \leq, 9$ & זr & لا تؤثر قدرة التلميذة النقدية على حصيلتها من المفردات والمصطلحات الفنية. & r \\
\hline$\Lambda \leq$ & $19 \varepsilon$ & 10 & $r \varepsilon$ & القدرة النقدية والتذوق للأعمال الفنية مهارتان منفصلتان. & $\varepsilon$ \\
\hline$\curlywedge \wedge, \varepsilon$ & $\varepsilon r$ & $\wedge 1,7$ & $1 \wedge 7$ & القدرة النقدية تُكن التلميذة من معرفة القيم الفنية. & ○ \\
\hline $11, \varepsilon$ & r & $\wedge \wedge, \uparrow$ & $r \cdot r$ & القدرة النقدية تهيئ التلميذة إلى تقبل النقد الموجه لعملها الفني. & 1 \\
\hline ז & 19. & $17, \mathrm{~V}$ & ऍ^ & نقد عمل التلميذة الفني يؤثر سلبا على تفاعلها مع مجموعتها. & v \\
\hline 10 & $r \varepsilon$ & 10 & $19 \varepsilon$ & النقد الفني يُكسب التلميذة قيما لغوية وفنية. & $\wedge$ \\
\hline 11,9 & $\varepsilon r$ & $\wedge$ & 110 & النقد الفني ينمي الجانب المعرفي لاى التلميذات. & 9 \\
\hline$\Lambda \vee, 0$ & ror & $M, 0$ & ז & النقد الفني لعمل التلميذة قبل انتهاءه تؤثر سلبا على التلميذة وعلى منتجها النهائي. & 1. \\
\hline$\Lambda \vee, 0$ & ror & $1, r, 0$ & r & المهارة النقدية تقتصر على الحكم على الأعمال الفنية. & 11 \\
\hline 11,9 & rV & $\wedge \wedge, 1$ & $r \cdot 1$ & المهارة النقدية تتمي التفكير العميق للى التلميذات قبل إصدار الأحكام. & ir \\
\hline 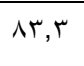 & rol & $17, r$ & rv & ممارسة النقد مع الأطفال تقلل من الإبداع في أعمالهم الفنية وتكسبهح نوع من التردد. & r \\
\hline
\end{tabular}




\begin{tabular}{|c|c|c|c|c|c|}
\hline $17, V$ & rs & זr, & 19. & المهارة النقدية تساعد التلميذات على تتمية القدرات الإبداعية. & $1 \varepsilon$ \\
\hline 19,1 & $\leqslant 0$ & $\Lambda \cdot, r$ & $1 / 1$ & تستطيع التلميذات بناء معايير خاصة بهم بعد فترة طويلة من ممارسة النقد الفني. & 10 \\
\hline$r \uparrow, r$ & 7. & $V \Psi, V$ & 171 & يوجد علاقة بين المهارة النقدية وتعديل سلوك التلميذات. & 17 \\
\hline$r \leqslant, 7$ & 07 & $\vee 0, \varepsilon$ & IVT & المهارة النقدية تساعد التلميذات على تحقيق التوازن الانفعالي. & IV \\
\hline$r r, y$ & $0 \leqslant$ & $v ч, r$ & $1 V \varepsilon$ & المهارة النقدية تشجع التلميذات على البحث والاطلاع. & 11 \\
\hline
\end{tabular}

من خلال تحليل النتائج التي تم الحصول عليها من المحور الثاني والذي يتعلق بقياس معلومات المعلمات في النقد الفني في ثلاثة

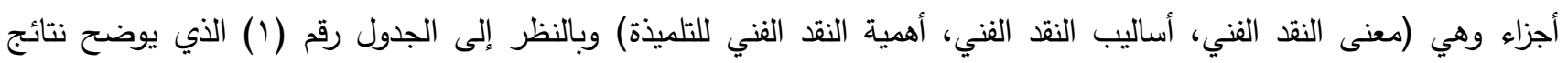

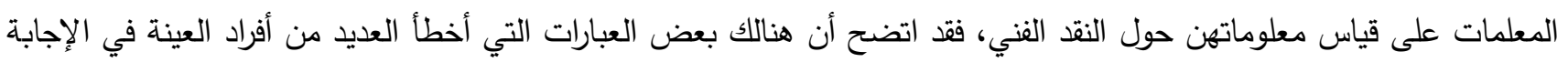

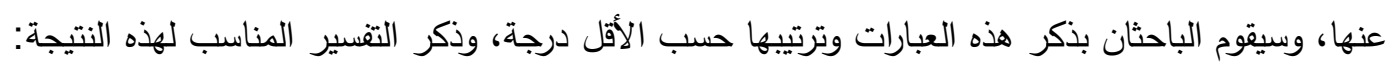

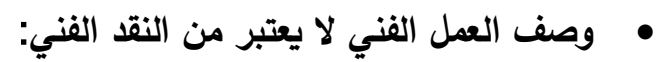

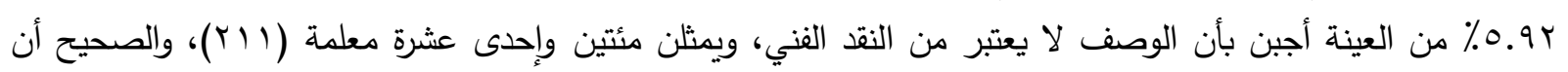

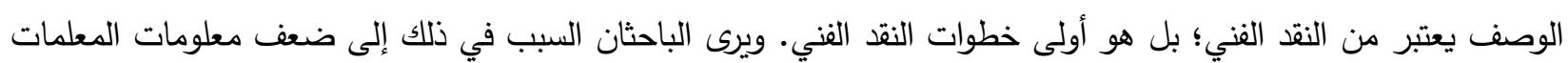
وعدم معرفتهن بخطوات النقد الفني حسب الطريقة العلمية، واعتمادهن على ملاحظة التقنيات في العمل. • من أساليب النقد الفني التحدث عن المشاعر التي يثيرها العمل الفني:

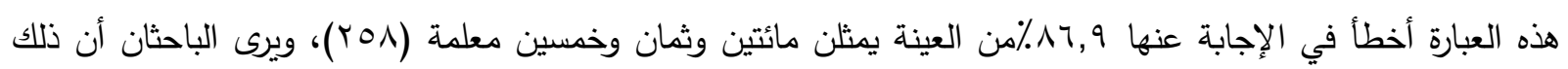

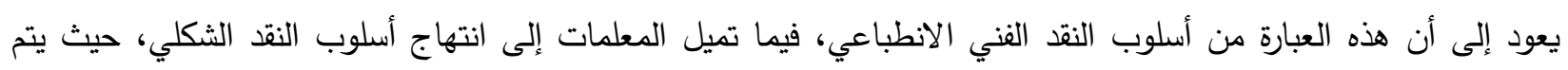

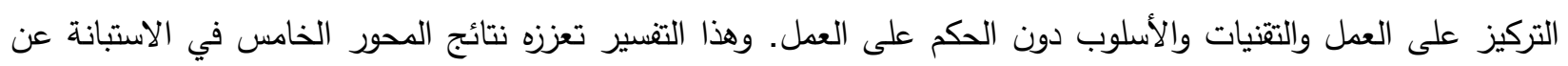

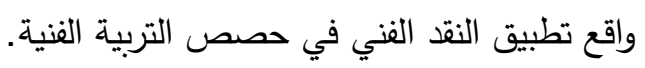

\section{• • لا تؤثر قدرة التلميذة النقدية على حصيلتها من المفردات وإلمصطلحات الفنية:}

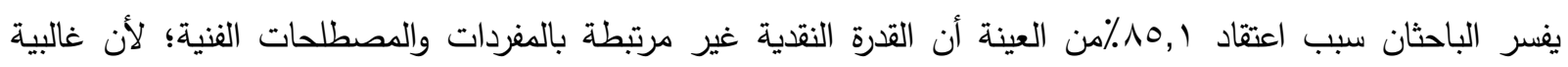
العينة لا يحدن معاييرا أو أسلوبا للنقد، كما لا يتم التخطيط للنقد الفني بشكل منظم، وبالتالي يصعب لفئ على العينة توقع النتائج من تفعيل النقد الفني. وهذه النسبة تشكل مائة وخمسا وتسعين معلمة (190 (1).

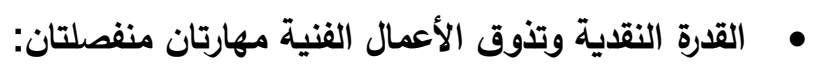

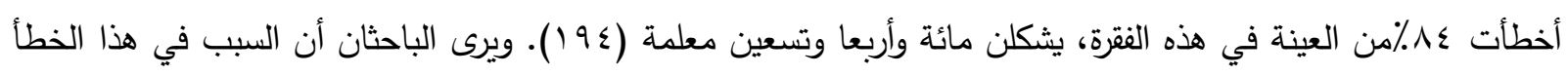

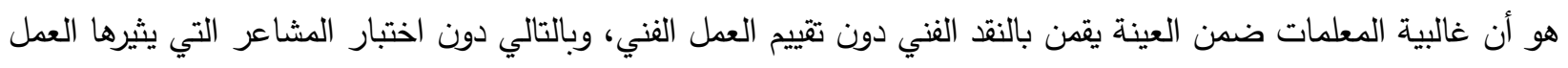
الفني في النفس، وبذلك فهن يفصلن ما بين النقد الفني والتذوق الفني، رغم أن هاتين المهارتين متصلتان. • النقد الفني لعمل التلميذة قبل انتهاءه يؤثر سلبا على التلميذة وعلى منتجها النهائي:

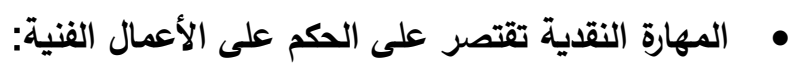
جاءت هاتان الفقرتان في المركز الخامس من العبارات التي أخطأ فيها أفراد العينة، حيث أخطأ أخطأ في الإجابة عنها

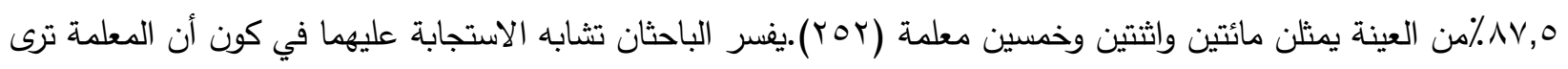

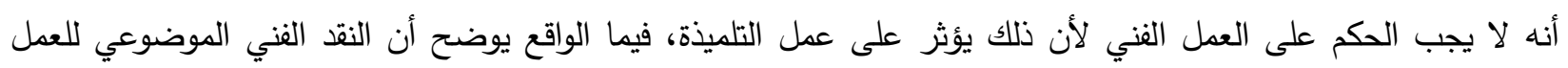
غير المكتمل يعطي التلميذة حلولا ومعالجات جديدة، وفرصة أكبر لتطوير العمل الفني.

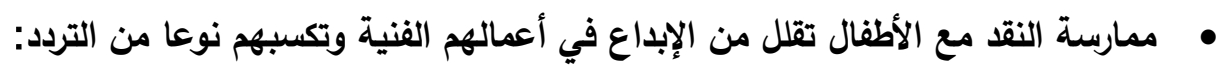

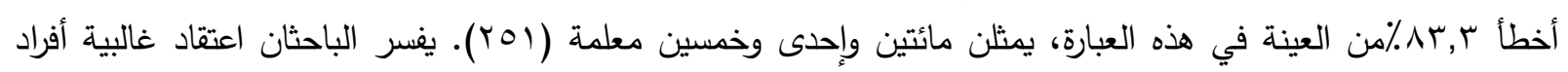
العينة أن هذه العبارة صحيحة، بأنه عند اتخاذ وجهة نظر المعلمة التي ترى أن النقد هو ذكر سلبيات وإيجابيات العمل إلتين الفني

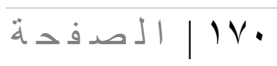


فقط، والتحقق من التقنيات والدعالجات دون اقتراح أي حلول أو تقنيات أو خامات جديدة، ودون ذكر المشاعر التي يثيرها العمل الفني، كل ذلك قد يحبط الطفل الصغير الذي يرى أن عمله رائع ومكتمل. • • نقد عمل التلميذة يؤثر سلبا على تفاعلها مع مجموعتها:

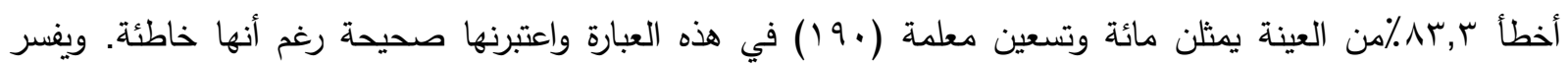

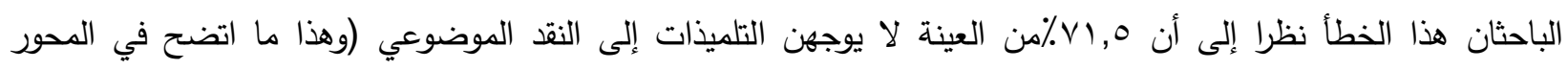
الخامس) بالتالي لابد أن تعتقد المعلمات أن النقد قد يؤثر سلبا على العلاقة بين التلميذة صاحبة العمل والتلميذة الناقدة لعملها.

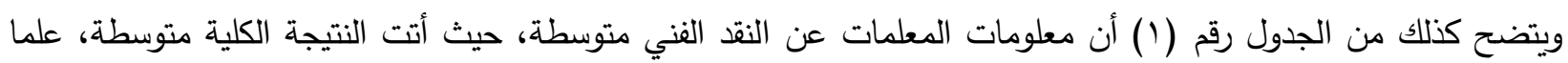

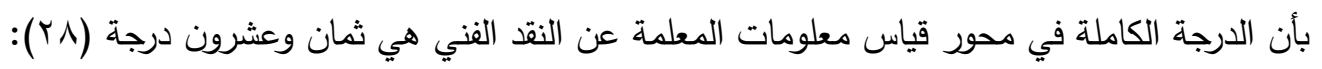
جدول (ץ): يوضح توزيع أفراد العينة حسب درجات قياس معلومات المعلمة في النقد الفني

\begin{tabular}{|c|c|c|}
\hline النسبة & 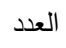 & الدرجة (من ^ץ) \\
\hline$\%$. & r & $(1 \cdot-1)$ \\
\hline$\% V r$ & 177 & $(r \cdot-11)$ \\
\hline$\%$ IV & rq & $(r \wedge-r \mid)$ \\
\hline$\% 1 \ldots$ & TYA & المجموع \\
\hline
\end{tabular}

ويدل ذلك على أن معلومات المعلمات تتفاوت ما بين المتوسطة والضعيفة، ولابد من تجديد هذه المعلومات وإنعاشها من جديد،

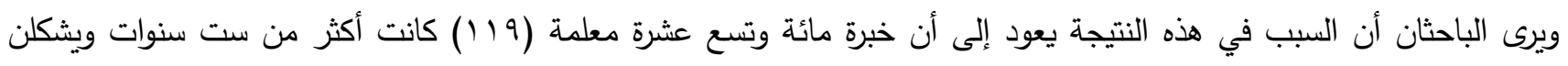

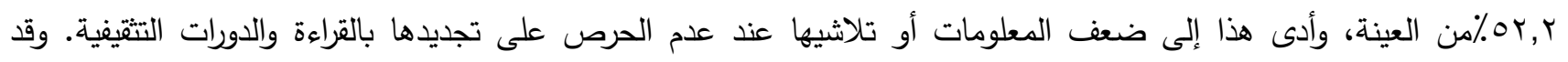
اتضح من المحور الأخير أن أغلب الضعف كان الن في الجزء الخاص بمعنى النقد الفني حيث كان عدد من حصلن على درجات

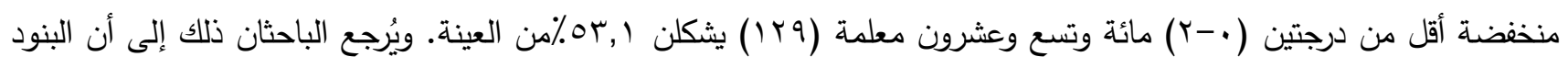

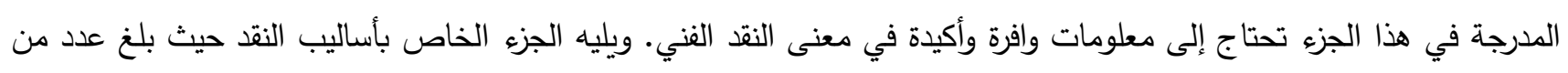

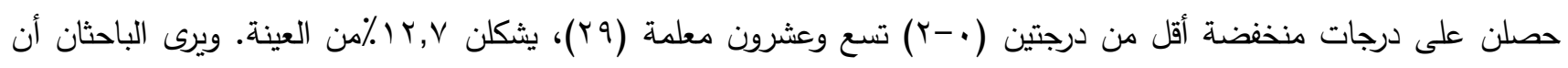

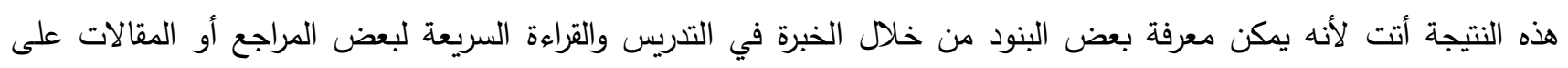

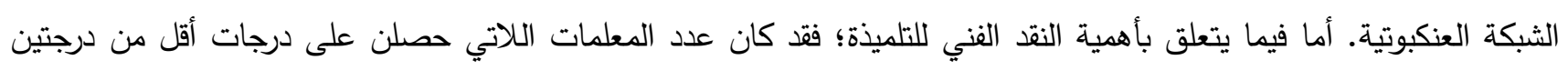

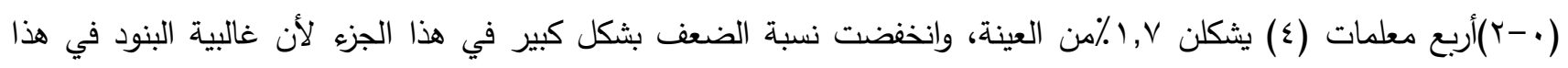

الجزء يمكن الاستدلال على صحتها من خلال الخبرة الطويلة في التدريس والمعرفة بخصائص نمو التلميذة في هذه المبات المرحلة. ثالثاً: مناقثة المحور الثالث والرابع والتي هي عبارة عن أسئلة مغلقة تجيب عن الأسئلة التالية:

$$
\text { ا . . هل يتم التخطيط لعملية النقد الفني في التخطيط الكتابي للدرس؟ }
$$

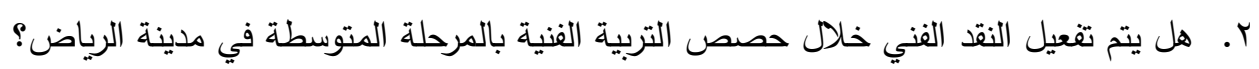

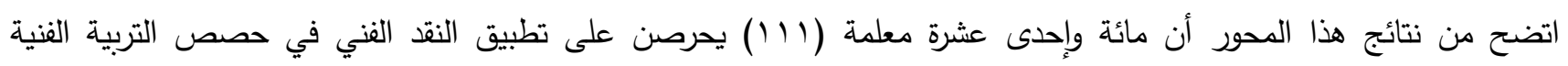

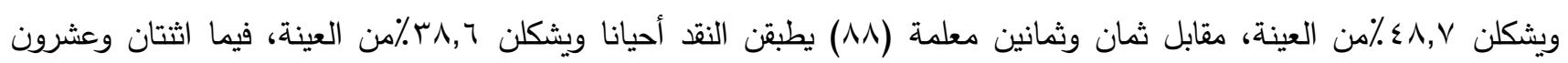

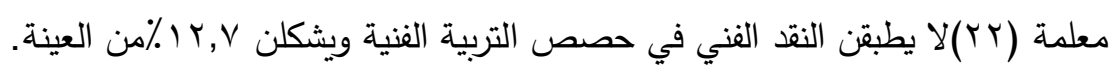




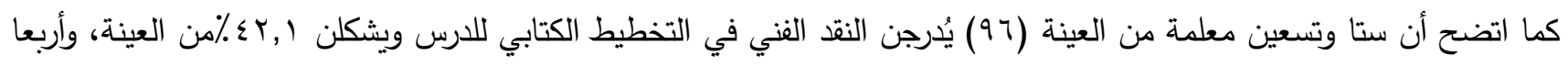

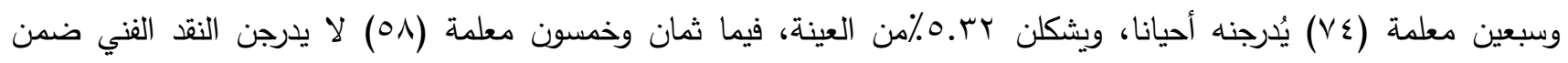

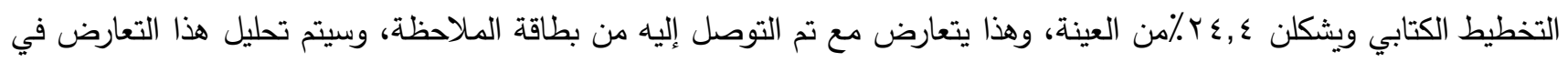

الجزء الخاص بتحليل ومناقشة بطاقة الملاحظة. بناء على النتائج التي تم الحصول عليها من هذا المحور تم توجيه أفراد العينة للاستجابة للمحور الخامس، حيث استجاب

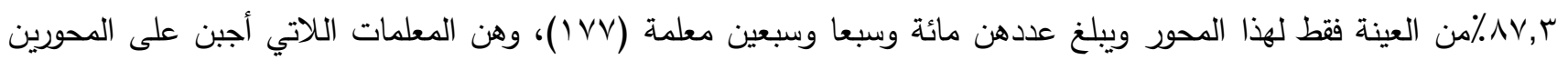
الثالث والرابع (نعم، أحيانا)، وتم استبعاد من اخترن الإجابة (لا) في هذين المحورين، حيث أن المحور التالي يتعلق بواقع التطبيق.

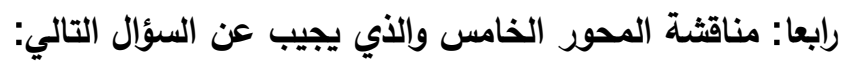

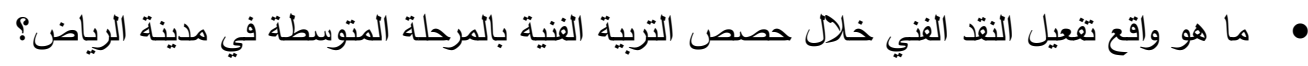

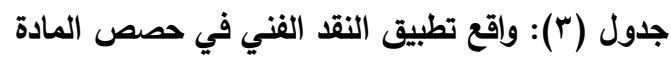

\begin{tabular}{|c|c|c|c|c|c|c|c|}
\hline$\%$ & لا & $\%$ & 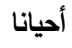 & $\%$ & نعم & 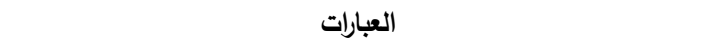 & r \\
\hline q & 7. & $\varepsilon r, 0$ & VV & $r r, T$ & $\varepsilon$ & أقوم بإدراج معايير النقد الفني في تخطيطي للدرس. & 1 \\
\hline $0 \wedge, r$ & $1 . r$ & $r \wedge, \wedge$ & 01 & $1 \pi$ & rt & أقوم بتدريب تلميذاتي على مهارة النقد الفني. & r \\
\hline$\vee 1,0$ & ITV & IV,o & r & $1 \cdot, \mathrm{V}$ & 19 & أوجه التلميذات إلى النقد الموضوعي. & $r$ \\
\hline$V Y, q$ & $1 r^{\prime}$ & 17,9 & r. & $1 \cdot, r$ & 11 & $\begin{array}{c}\text { أفسح المجال للتلميذات باقتراح الحلول أو المعالجات أو الوسائط التي من المكن استخدامها في المنتج الفني. } \\
\text { المني }\end{array}$ & $\varepsilon$ \\
\hline 00,9 & 99 & ro,1 & Tt & 9 & 17 & تُمارس تلميذاتي النقد الفني خلال حصص المادة & 0 \\
\hline$\varepsilon \uparrow, \varepsilon$ & $11 \varepsilon$ & $r \wedge, \Lambda$ & 01 & $\uparrow, \wedge$ & Ir & خلال عملية النقد الفني تقوم التلميذات بالحكم على العمل الفني. & 7 \\
\hline$\pi$ & $11 \pi$ & $1 \cdot, \mathrm{V}$ & 19 & $r_{0, \varepsilon}$ & «o & خلال عملية النقد الفني تتم المقارنة بين أكثر من عمل. & $v$ \\
\hline$\wedge \wedge, 1$ & 107 & 11,9 & r) & . & · & أوجه التلميذات لذكر الإيجابيات في العمل إضافة للسلبيات. & $\wedge$ \\
\hline rq,० & $v \cdot$ & ra, r & $T \varepsilon$ & $r \varepsilon, r$ & $\varepsilon r$ & يتم القيام بحلقة نقد مع التلميذات لنقد الأعمال الفنية. & 9 \\
\hline $9 . \leqslant 7$ & N & $r_{4, \mathrm{~V}}$ & 70 & $17, \varepsilon$ & rq & 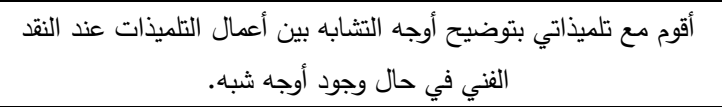 & 1. \\
\hline$r \cdot, 0$ & $0 \leqslant$ & 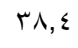 & $\uparrow 1$ & M, & 00 & يتم استخدام أسلوب العصف الذهني عند النقد الفني مع التلميذات. & 11 \\
\hline$\varepsilon \cdot, 1$ & VI & $r, \Lambda$ & 01 & $r V, 1$ & $\leqslant 1$ & أقوم مع تلميذاتي بنقد أعمال لسنوات سابقة أو صفوف أخرى. & ir \\
\hline 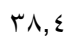 & 71 & rq, $\varepsilon$ & or & Mr, & ov & أقوم مع تلميذاتي بنقد المعرض المدرسي والتعليق على الأعمال الفنية. & ir \\
\hline
\end{tabular}

يوضح الجدول رقم (r) أن سبعا وسبعين معلمة (VV) يقمن بإدراج معايير للنقد الفني في التخطيط الكتابي أحيانا ويشكلن

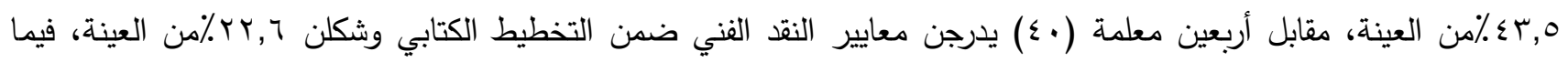

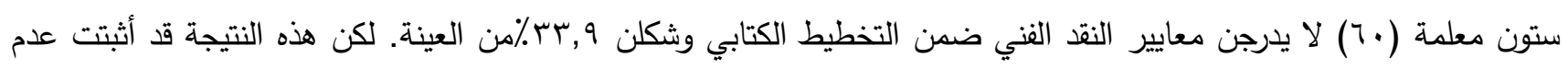

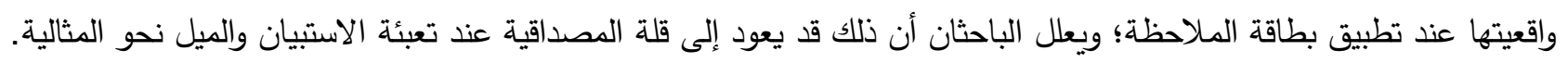


تقوم ثلاث وعشرون معلمة (rT) بتدريب تلميذاتهن على مهارة النقد الفني، وشكلن r 1\%من العينة، فيما تقوم إحدى وخمسون

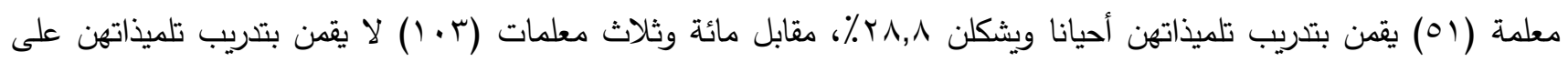

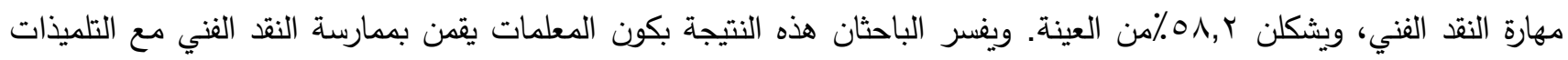

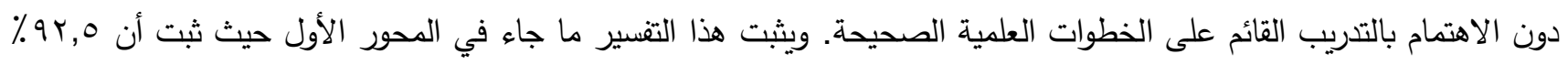
من العينة يجهلن خطوات النقد الفني.

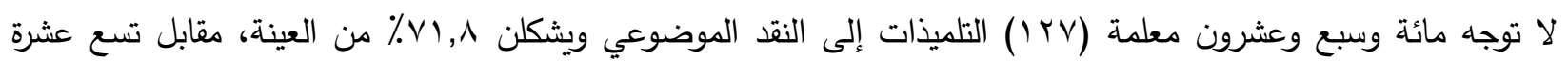

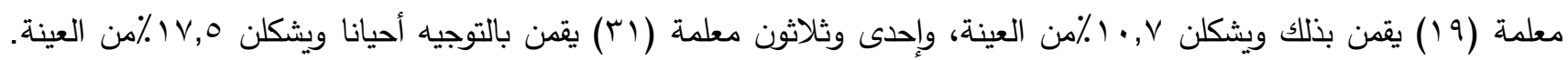

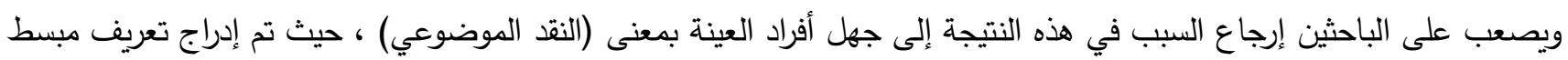
له في هامش أداة البحث، لذلك يرى الباحثان أن هذه النتيجة تعود إلى كون المعلمات لا يوجهن تلميذاتهن، وهذا يتتاسب مع نتيجة النقرة السابقة.

لا تميل المعلمات لإفساح المجال للتلميذات باقتراح الحلول أو المعالجات أو الوسائط التي يمكن استخدامها في المنتج الفني

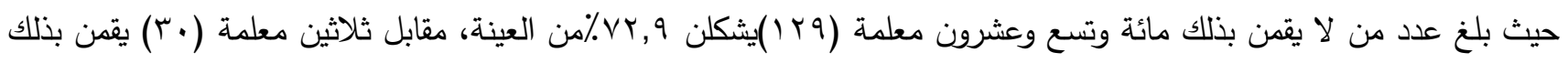

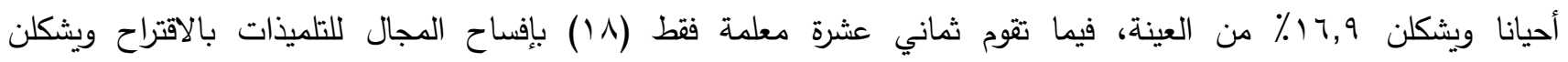
r, • ( ٪. ويفسر الباحثان هذه النتيجة بأن المعلمة تُلزم التلميذات بعدد من التقنيات والوسائط دون إفساح المجال لاستخدام مواد بديلة أو طرق جديدة، وهذا التقسير تم التوصل إليه بعد الاطلاع على الخطط الموزعة على معلمات التربية الفنية من قبل إدارة التعليم.

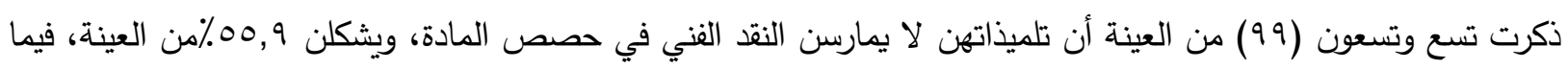

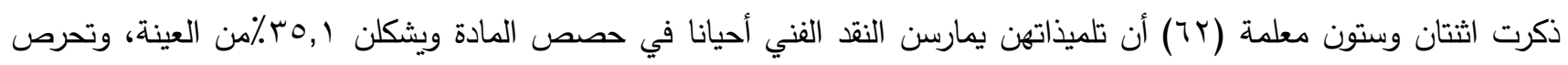
ست عشرة (7 () مَنْ يحرصن على أن تمارس التلميذات النقد الفني خلال حصص المادة ويشكلن و ٪/من العينة.

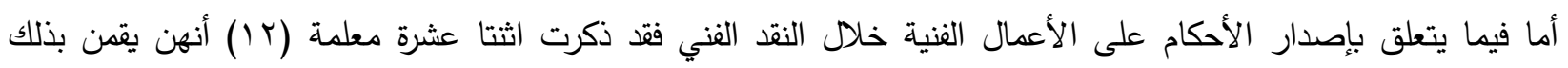

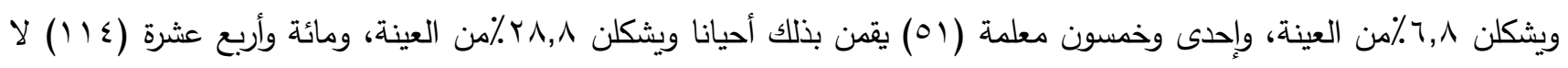

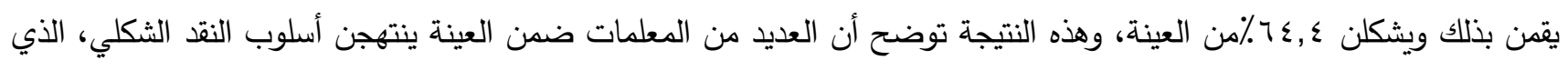
لا يُصدر الأحكام على العمل الفني ولا يتم تقييمه. تقوم إحدى وعشرون معلمة فقط (Y) أحيانا بتوجيه التلميذات لذكر السلبيات والإيجابيات في العمل الفني أثناء النقد الفني

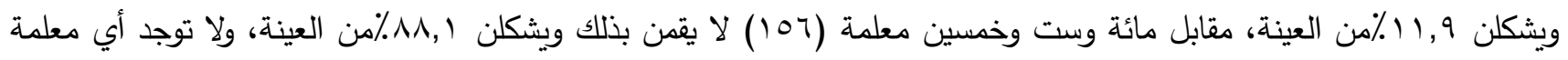

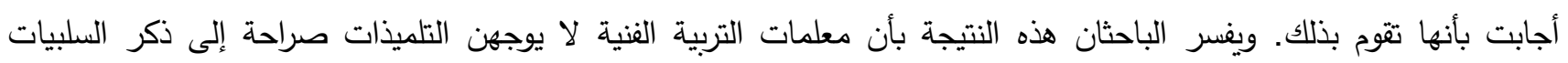

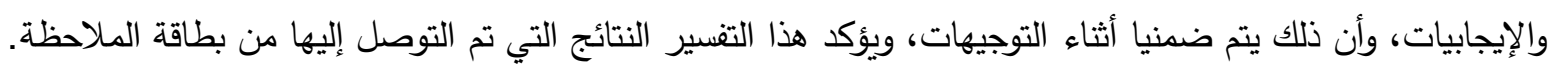

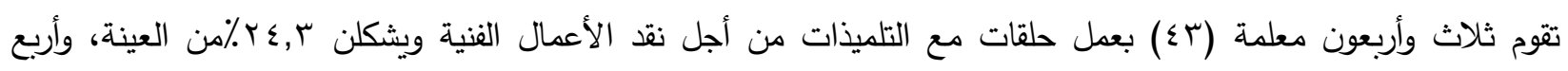

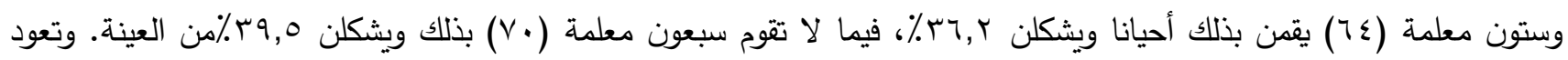

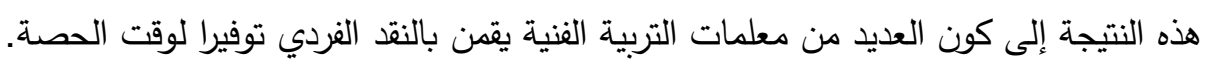

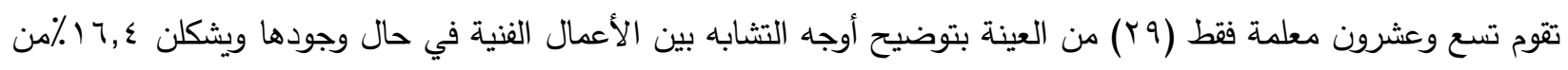

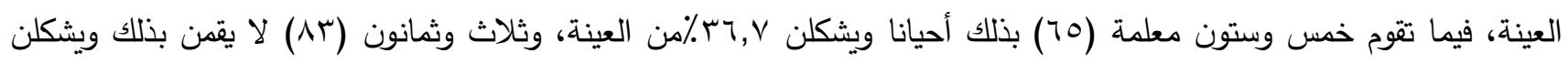

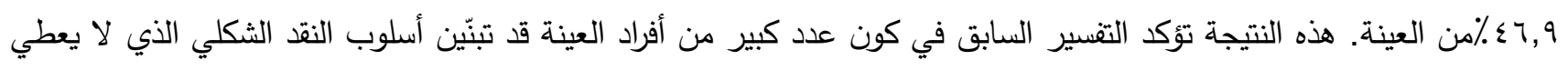
اهتماما للمقارنة بين الأعمال الفنية.

ذكرت خمس وخمسون معلمة (00) أنهن يقمن باستخدام أسلوب العصف الذهني مع التلميذات عند النقد الفني ويشكلن

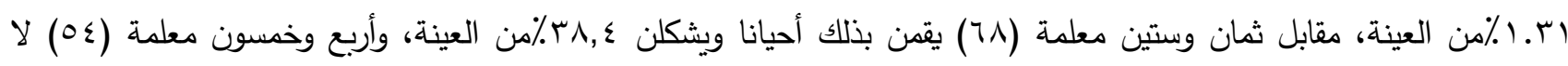

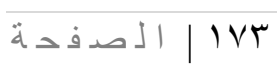


يقدن باستخدام هذا الأسلوب ويشكلن 0, • ؟٪من العينة. يعتبر الباحثان أن هذه النتيجة جيدة، وتدل على أنه يتم استخدام الأساليب

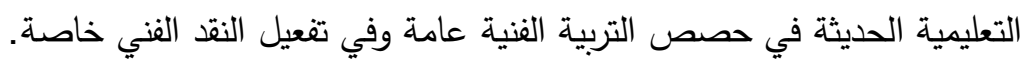

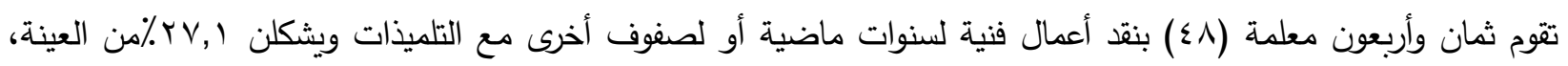

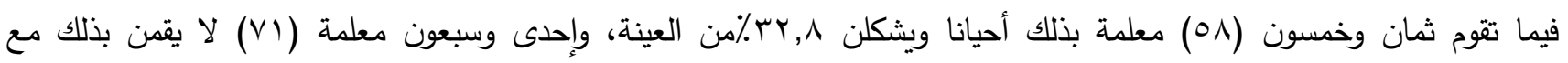

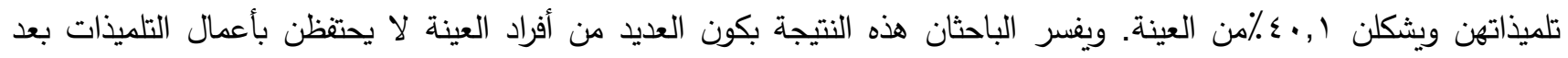

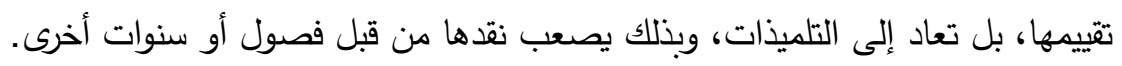

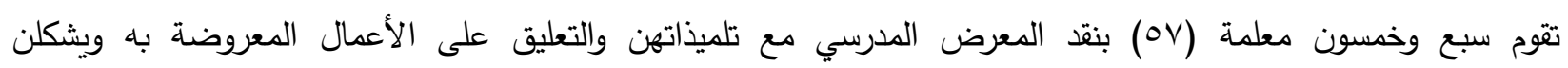

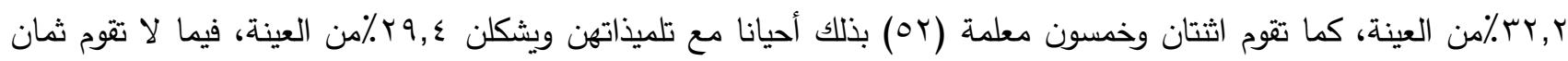

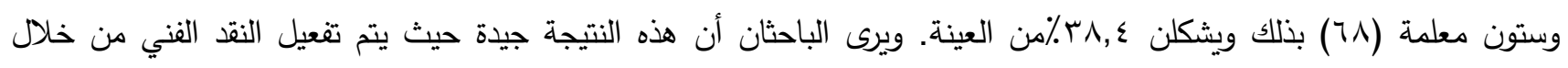

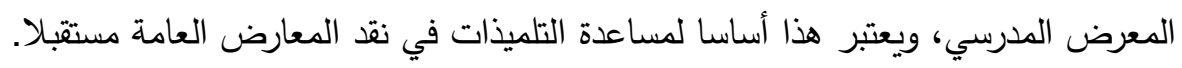

\section{عرض ومناقشة نتائج بطاقة الملاحظة:}

أولا: مناقشة بنود بطاقة الملاحظة والتي تم تطبيقها على عينة عشوائية تمثل ربع مجتمع البحث وعددها اثنتان وستون (rآ) معلمة. والهدف منها التحقق من النتائج التي تم الحصول عليها من خلال الاستبانة، بالإضافة إلى التحقق من الأهداف التالية:

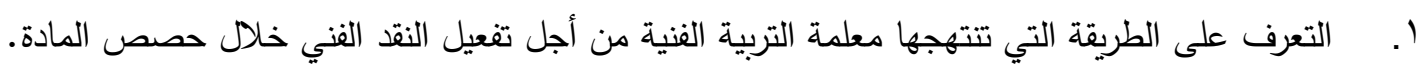
r. الت التعرف على واقع تفعيل النقد الفني خلال حصص التربية الفنية بالمرحلة المتوسطة في مدينة الرياض.

توزيع أفراد العينة حسب المؤهل:

أفراد العينة اللائي تم تطبيق بطاقة الملاحظة عليهن كن تسع عشرة معلمة (9 (1) يحملن مؤهل الدبلوم ويمثلن ؟1/من

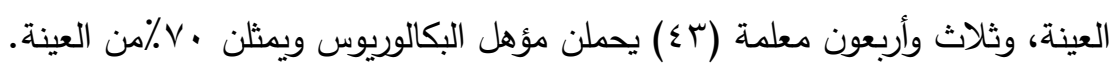
توزيع أفراد العينة حسب مصدر المؤهل:

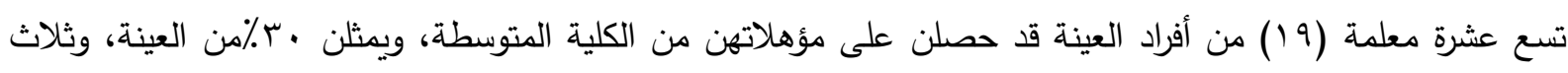

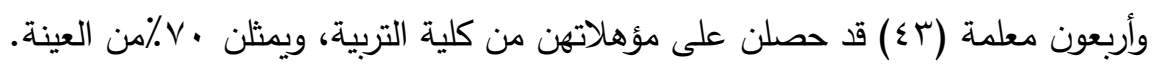
توزيع أفراد العينة حسب التخصص: خمسون معلمة (•0) من أفراد العينة تخصصن في التربية الفنية وشكلن ؟, •ــ/من العينة، مقابل اثنتي عشرة معلمة

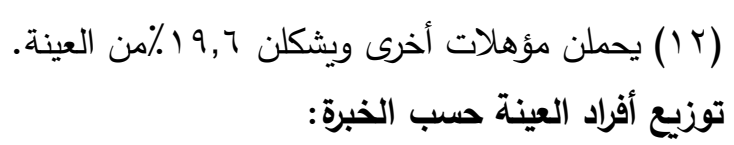

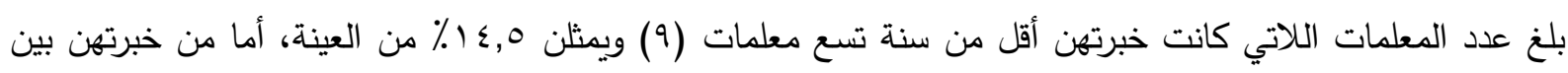

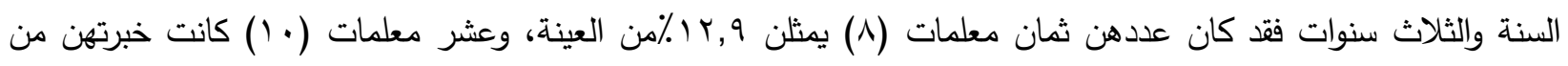

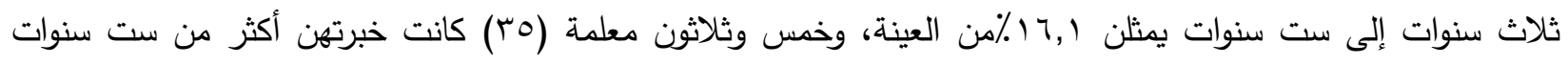

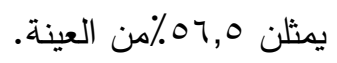


جدول رقم(؛): نتائج بطاقة الملاحظة حول تطبيق النقد الفني في حصص المادة، وإدراجه في دفتر تحضير الاروس

\begin{tabular}{|c|c|c|c|c|c|}
\hline$\%$ & لط يتم & $\%$ & تطبيقه & 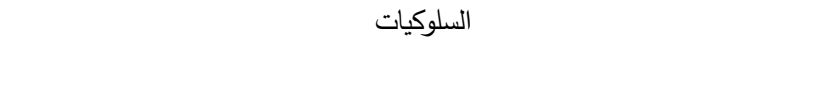 & \\
\hline \multicolumn{6}{|c|}{ أ. خلال حصة التربية الفنية } \\
\hline $1 \cdots$ & Tr & • & • & شرحت المعلمة للتلميذات أسلوب النقد المتبع. & \\
\hline $11, r$ & V & $\wedge \wedge, \vee$ & 00 & عرضت المعلمة أعمال التلميذات قبل نهاية الحصة. & \\
\hline $1 \cdots$ & Tr & - & • & دونت المعلمة معايير النقد . & \\
\hline $1 \varepsilon, 0$ & 9 & 10,0 & or & قامت المعلمة بتعريف التلميذات بينود ومعايير النقد & \\
\hline $9, V$ & 7 & $9 \cdot, r$ & 07 & مارست المعلمة النقد الفني على أعمال التلميذات. & \\
\hline$r \varepsilon, r$ & 10 & $\vee \circ, \wedge$ & $\varepsilon V$ & شجعت المعلمة التلميذات على ممارسة النقد الفني & \\
\hline ro,, & 17 & $V \varepsilon, r$ & $\varepsilon\rceil$ & مارست التلميذات النقد الفني. & \\
\hline$r \cdot, 7$ & 19 & $79, \varepsilon$ & $\varepsilon r$ & وجهت المعلمة التلميذات للتحدث عن عملهن الفني (النقد الذاتي) & \\
\hline ro,, & 17 & $V \varepsilon, r$ & $\varepsilon 7$ & وجهت المعلمة التلميذات لذكر ايجابيات العمل الفني أثناء النقد الفني & \\
\hline$r \varepsilon, r$ & 10 & $\vee 0, \wedge$ & $\varepsilon V$ & وجهت المعلمة التلميذات لذكر سلبيات العمل & \\
\hline 17,1 & $1 \cdot$ & Ar,q & or & شجعت المعلمة التلميذات على تقبل رأي زميلاتهم في أعمالهن. & \\
\hline $9, \mathrm{~V}$ & 7 & $q \cdot, r$ & 07 & تم تجنب الحكم على العمل الفني بأحد العبارات التالية (جيد- رديء- متقن... الخ). & \\
\hline \multicolumn{6}{|c|}{ ب. دفتر تحضير الدروس (التخطيط اليومي) } \\
\hline$\wedge 0,0$ & or & $1 \leqslant, 0$ & 9 & إدراج النقد الفني ضمن الأهداف. & \\
\hline 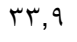 & Yl & 77,1 & $\varepsilon 1$ & تحديد ضمن عرض الدرس إجراءات لتفعيل النقد الفني. & \\
\hline$T V, V$ & $\varepsilon r$ & r & r. & ذكر الوسائل التعليمية التي سيتم استخدامها لشرح النقد الفني للتلميذات. & \\
\hline$\vee \vee, \Sigma$ & $\varepsilon \wedge$ & $r, T$ & $1 \leq$ & استخدام مراجع فنية لإثراء جانب النقد الفني في الدروس. & \\
\hline \multicolumn{6}{|c|}{ ج. دفتر تحضير الدروس (التخطيط السنوي/الثهري) } \\
\hline $1 \cdots$ & Tr & • & · & إدراج النقد الفني ضمن الأهداف. & \\
\hline 07,0 & ro & $\varepsilon r, 0$ & rV & ذكر الوسائل التعليمية التي سيتم استخدامها لشرح النقد الفني للتلميذات. & \\
\hline $1 \cdots$ & $7 r$ & • & • & استخدام مراجع فنية لإثراء جانب النقد الفني في الدروس. & \\
\hline
\end{tabular}

\section{نتائج بطاقة الملاحظة حسب المحاور التالية: ا الس السلوكيات خلال حصة التربية الفنية:}

يتضح من الجدول رقم (乏) أنه لم تقم أي معلمة بشرح أسلوب النقد المتبع. وعرضت خمس وخمسون معلمة (00)

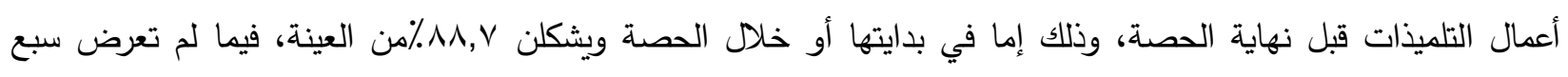

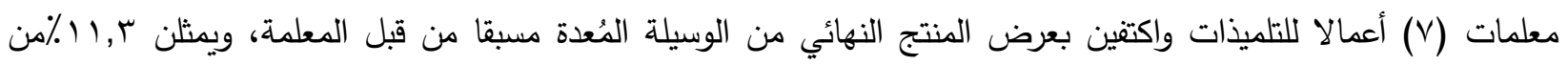


العينة. يفسر الباحثان وجود r,11\%من العينة لم يقمن بعرض أعمال التلميذات بسبب انتهاء الحصة قبل إكمال التلميذات لأعمالهن الفنية.

قبل القيام بالنقد من قبل التلميذات أو المعلمة، تم تحديد بنود النقد من قبل ثلاث وخمسين معلمة (بهم) يمثلن

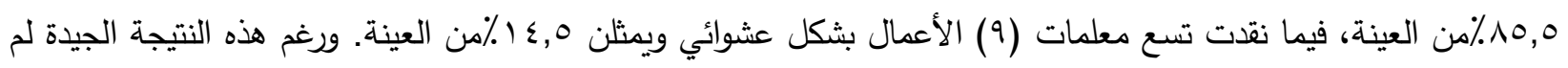
تقم أي معلمة بتدوين بنود النقد على السبورة كما لم تحضر أي واحدة منهن وسيلة معدة مسبقا، بل اكتفين بالذكر الثفهي. وهذا

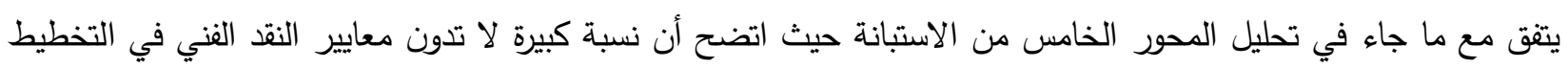
الكتابي للدرس.

لقد مارست ست وخمسون معلمة (70) النقد الفني على أعمال تلميذاتهن ويشكلن r, •9٪من العينة، مقابل ست

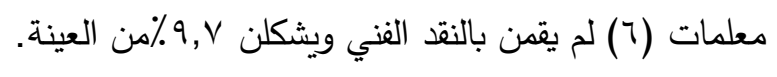

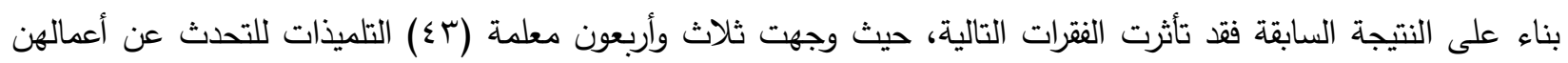

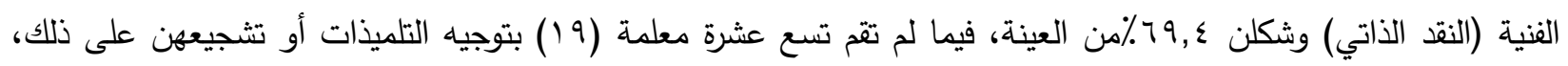

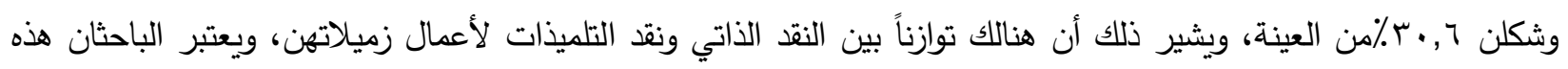

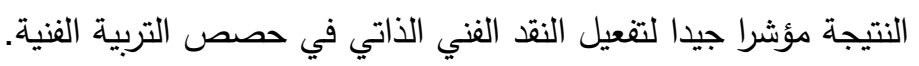

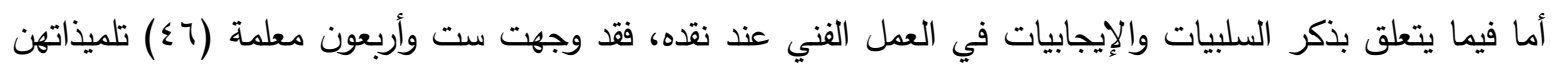

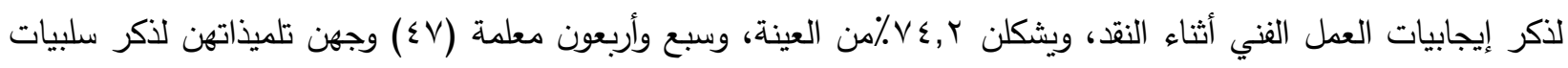

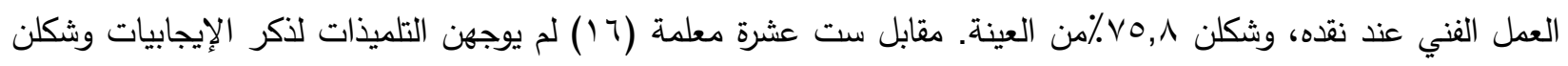

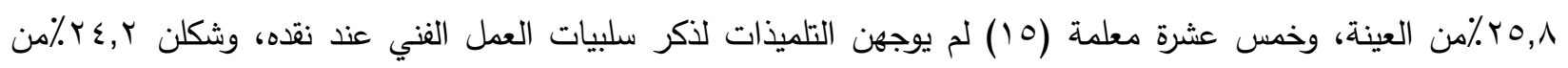
العينة.

ويتعارض هذا مع ما جاء في تحليل الفقرة الثامنة من المحور الخامس من الاستبانة التي تثير إلى توجيه المعلمة

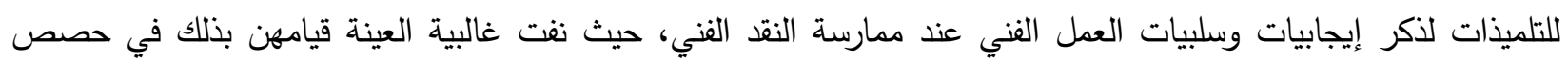
المادة، وأثبت ذلك التقسير الذي تبناه الباحثان في كون العينة توجه التلميذات بشكل ضمني لذيات لذكر سلبيات وإيجابيات العمل الفني عند نقده وليس توجيها صريحاً. في نهاية النقد حرصت ست وخمسون معلمة (70) على عدم تقييم العمل الفني أو الحكم عليه وتصنيفه بعبارات مثل (جيد،

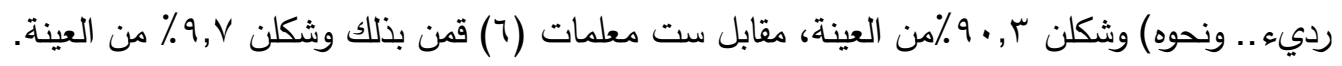

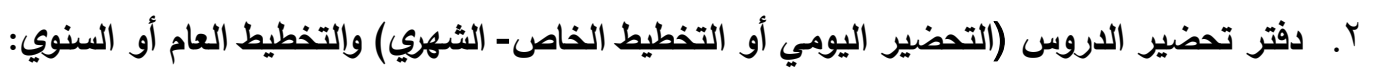
فيما يختص بدفتر تحضير الدروس فقد قامت تسع معلمات فقط (9) بإدراج النقد الفني ضمن أهداف الدرس في في أني

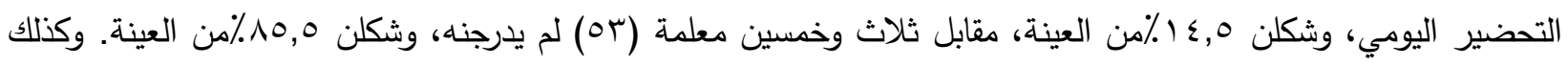
لم تقم أي معلمة بإدراج النقد الفني ضمن التخطيط الخاص أو العام. ويرى الباحثان أن ذلك يعود إلى اعتماد معلمات التربية

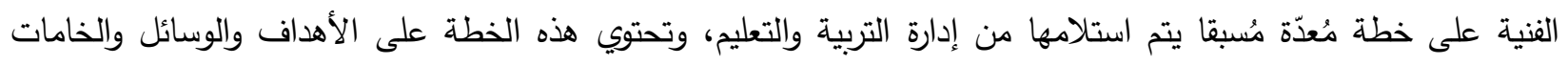

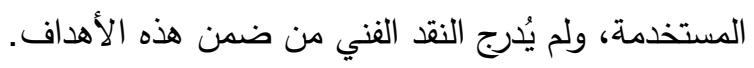
ويتعارض هذا مع النتيجة السابقة التي تم التوصل إليها من المحور الرابع في الاستبانة، حيث أجابت أغلب أفراد العينة

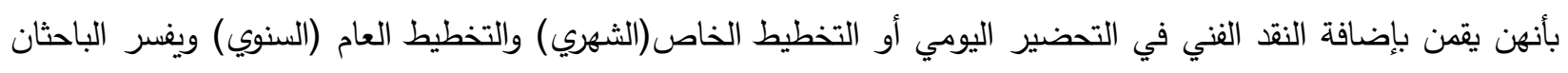
ذلك إلى ميل أغلب أفراد العينة إلى عدم الدقة عند تعبئة الاستبيان والميل إلى المثالية.

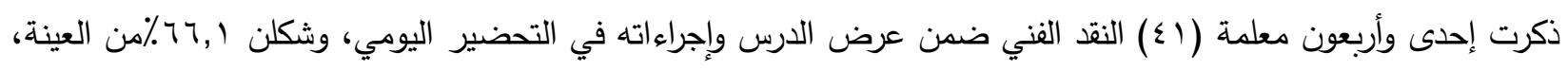

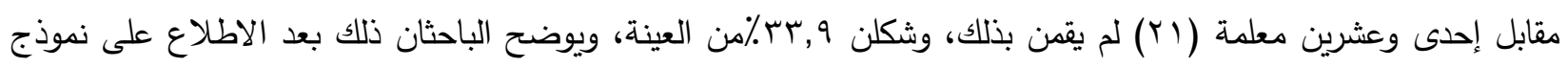


التحضير للمعلمات اللاتي كُن ضمن عينة المُلاحظة أن النقد الفني تم إدراجه كأحد العناصر في تتييم الدرس، دون توضيح أي خطوات لتفعيله أو ذكر أي معايير.

ذكرت عشرون معلمة (•r) الوسائل التعليمية التي سيتم استخدامها لتقعيل النقد الفني في التحضير اليومي، ويشكلن

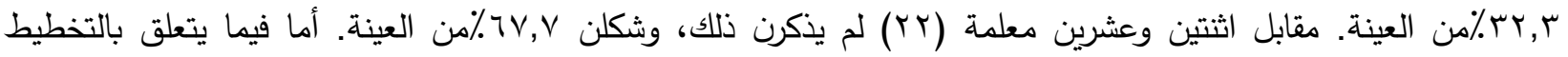
الخاص والعام فقد قامت سبع وعشرون معلمة (YV) بإضافة بعض الوسائل الخاصة بالنقد الفني على الخطة المعتمدة من إدارة

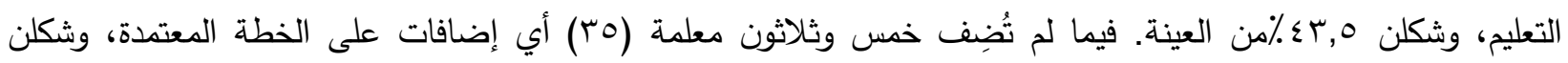

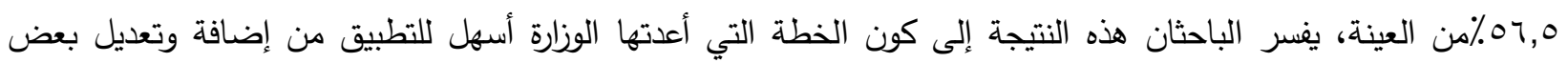

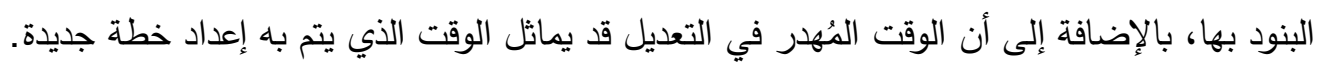

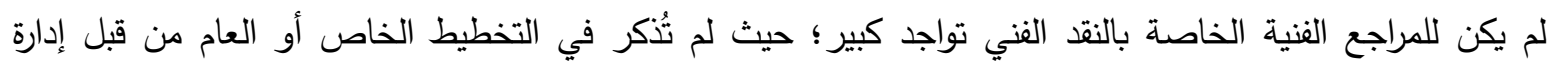

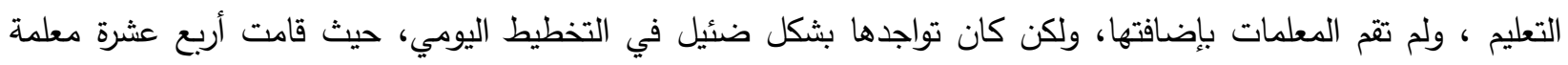

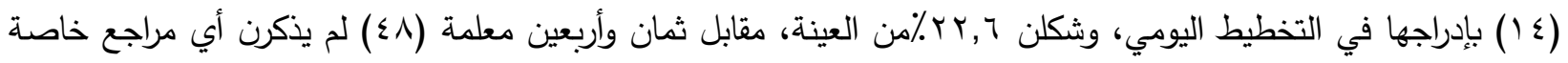

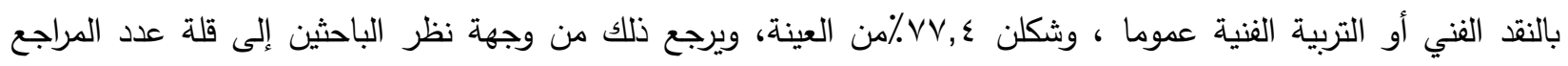

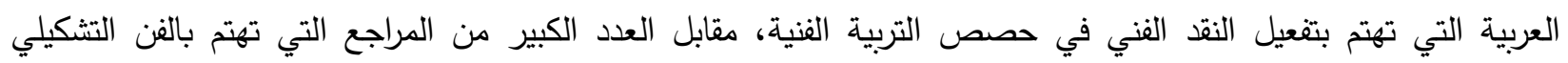

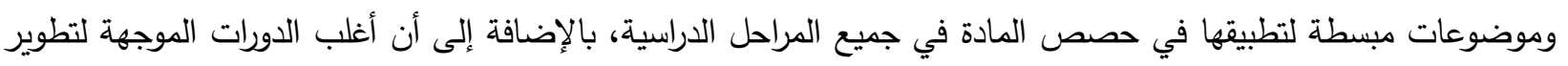

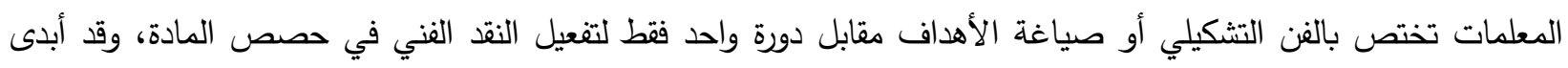
أغلب أفراد العينة عند سؤالهن عن سبب عدم التحاقهن بالدورة أنهن يجهلن عن وجود دورات مخصصة للنقد الفني موجهة لمعلمات التربية الفنية.

$$
\text { ملخص نتائج البحث: }
$$

هدف هذا البحث إلى تقويم تدريس معلمات التربية الفنية بالمرحلة المتوسطة في مدينة الرياض لمهارات النقد الفني، وتم استخلاص العديد من النتائج، وسوف يورد الباحثان أهم النتائج والتقسيرات التي توصل إليها البحث بشكل أكثر تركيزا وتلخيصا، لثربه

$$
\text { وهي كالتالي: }
$$

\section{أولاً: ممارسة وتفعيل النقد الفني في المرحلة المتوسطة:}

ا. لا تقوم المعلمات بشرح الأسلوب النقدي المتبع للتلميذات، ولا يتم تحديد أي الأساليب النقدية سيتم انتهاجها خلال العام

$$
\text { الدراسي. }
$$

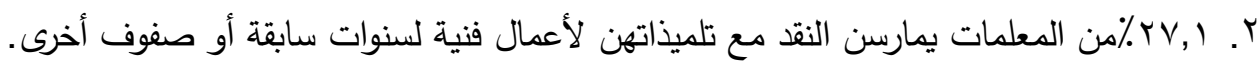

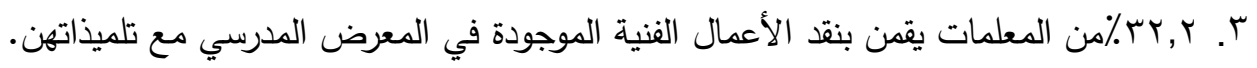

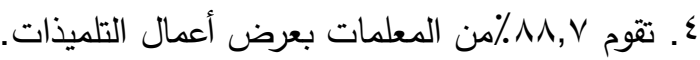

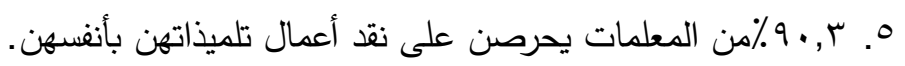

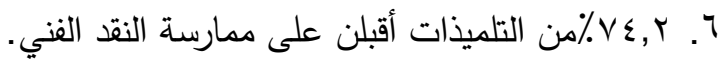

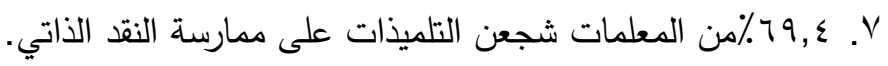

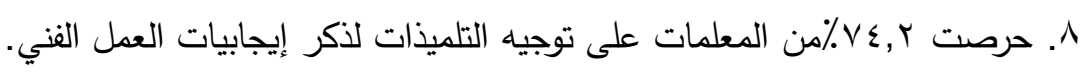

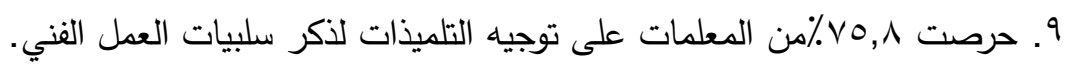

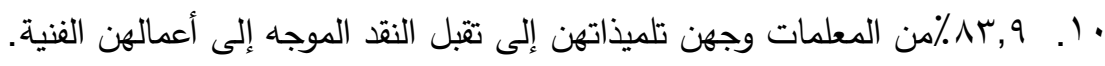




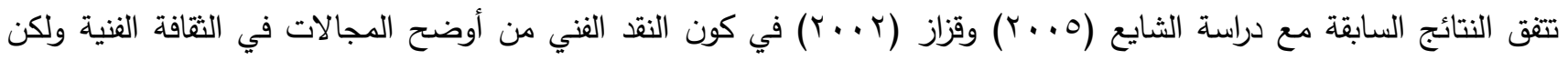
يفتقد إلى التطبيقات التربوية المناسبة مع جميع الأساليب النقدية، كما توضح أهمية أن يتم تدريس النقد الفني في جميع المراحل التعليمية، متبعين بذلك القواعد والمعايير ويتم تحديد الأساليب التربوية.

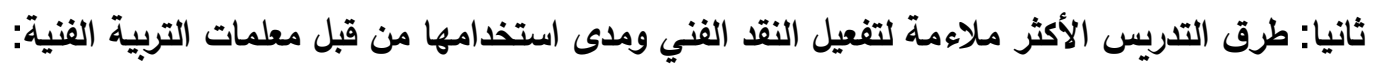

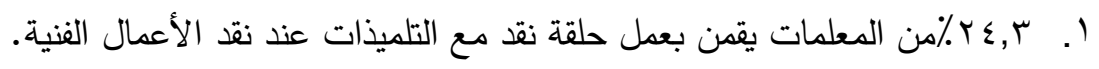
r. تستخدم المعلمات الأساليب الجديدة في شرح الدرس، وقمنّ بتفعيلها في مراحل الدرس المختلفة، حيث استخدمت

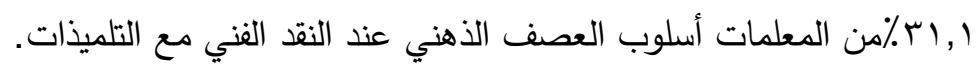

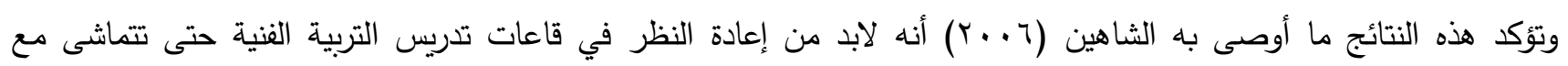
المتطلبات التعليمية وطرق التدريس الحديثة، حيث أن أغلب قاعات الدراسة ما تزال غير مهيأة لاستخدام طرق حديثة في التدابه لتاديس. ثالثاً: التحضير اليومي للاروس والخطط الخاصة (الثهرية) /الخطط العامة (السنوية):

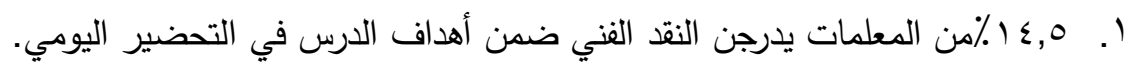
r. ب. لا تقوم المعلمات بإدراج النقد الفني ضمن أهداف الخطة في الخطة الخاصة (الشهرية)أو الخطة العامة (السنوية).

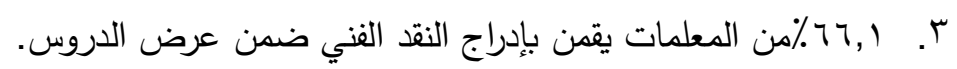

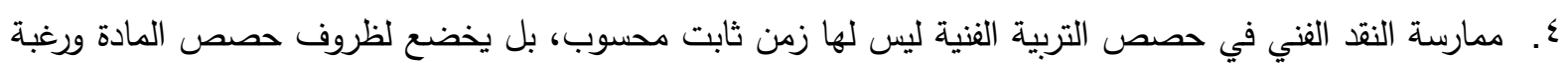
المعلمة.

تتفق هذه النتائج مع دراسة جسومه (997) والغامدي (999 (1999) والثربتي (999 (1) في أهمية صياغة الأهداف في منهج التربية الفنية وتطويرها لتتناسب مع الاتجاهات المعاصرة في التدريس، بالإضافة إلى قدم محتوى منهج التربية الفنية المعدول به حاليا، وعدم اهتمام معلم التربية الفنية بتتمية ثقافة التلميذ وتركيزه على إنتاجه الفني، وبذلك لابد من تطوير منهج التربية الفنية لمعالجة القصور وتوجيه المعلم للاهتمام بجميع عناصر الثقافة الفنية عند وضع الأهداف والتخطيط للدروس.

رابعاً: الوسائل التعليمية المستخدمة والوسائط والمراجع التي يستعين بها المعلم عند تفعيل النقد الفني في حصص المص المادة:

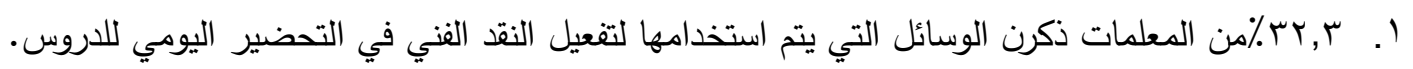

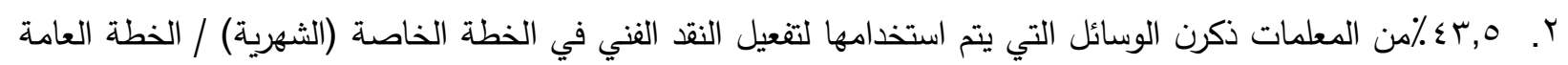
(السنوية) للدروس.

r. ل لا تقوم معلمات التربية الفنية باستخدام مراجع خاصة بالنقد الفني أو مراجع للتربية الفنية عامة في الخطة الخاصة

$$
\text { (الثهرية) ولا في الخطة العامة (السنوية). }
$$

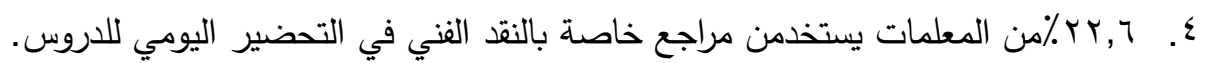

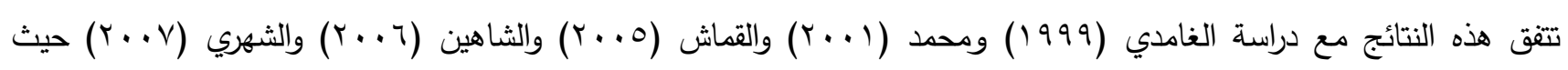
أجمعوا على عدم وجود وسائل تساعد المعلم على تثتيف التلميذ فنيا، وضرورة إلمام معلم التربية الفنية بالوسائط الحديثة المستخدمة

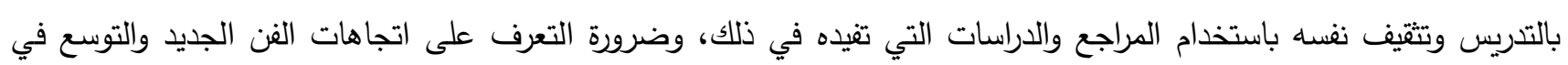
مجال النقد الفني. خامساً: اهتمام الإدارة المدرسية بتطوير معلم التربية الفنية:

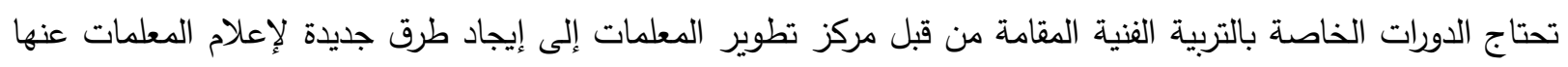
والتسجيل فيها، حيث لم تلتحق r, ؟ ؛ ٪من العينة بأي دورات خاصة بالتربية الفنية. وهذا يؤكد ما توصل إليه الغامدي (999 (19) من عدم اهتمام الإدارة المدرسية بمادة التربية الفنية وتطوير معلم التربية الفنية. 
سادساً: معلومات معلم التربية الفنية:

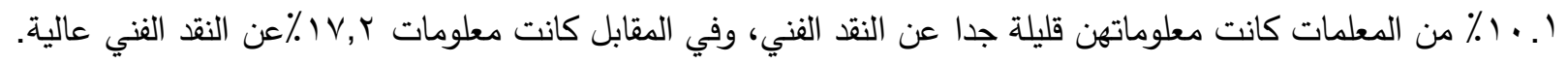

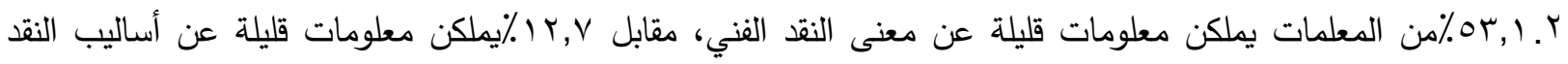

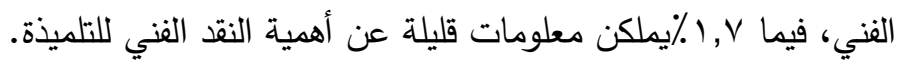

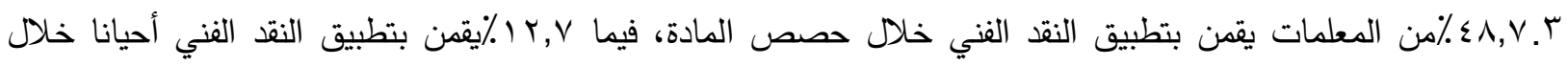

الحصة، وذلك اعتماداً على الظروف دون تخطيط أو تتظيم للعملية.

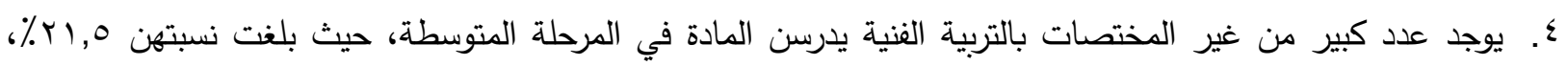

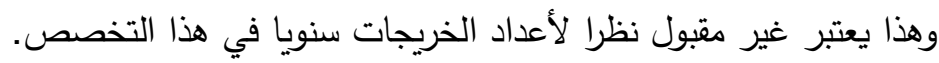

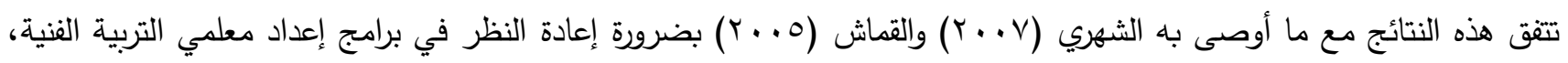

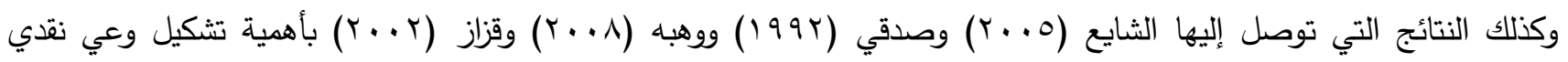

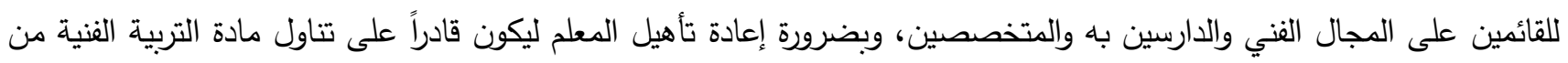
منظور جديد، وأن ذلك يؤثر إيجابا على أداء المعلمين وعلى النتائج التعليمية لدى التلاميذ وتطور تفكيرهم الناقد.

سابعاً: تطوير التعليم والمناهج الخاصة بمادة التربية الفنية:

ا ـ لا تدرك العديد من المعلمات أنهن يقمن بالنقد الفني خلال حصص المص المادة، وقد يعود ذلك إلى عدم إلمام بالمسميات،

وإلى التردد عند تعبئة الاستبيان.

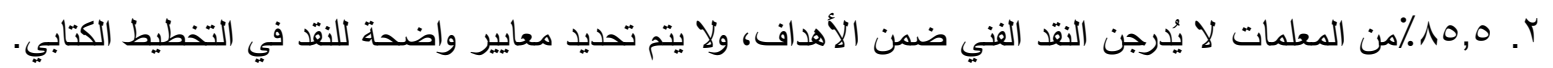

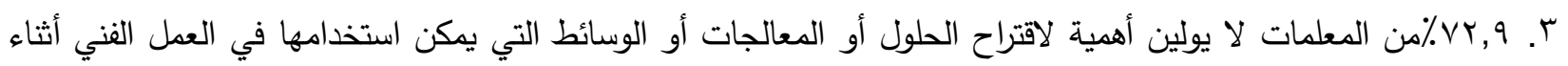
النقد الفني.

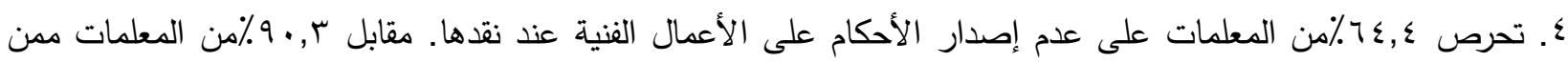
قابلهن الباحثان يحرصن على عدم تقييم العمل وتصنيفه بجيد أو رديء.

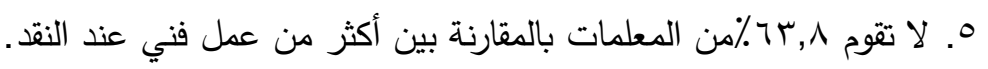

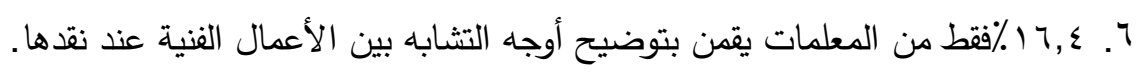

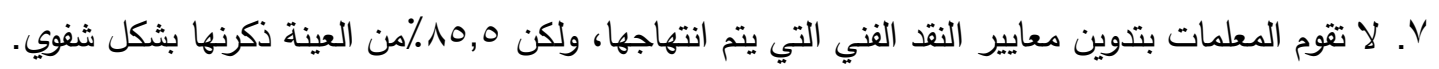

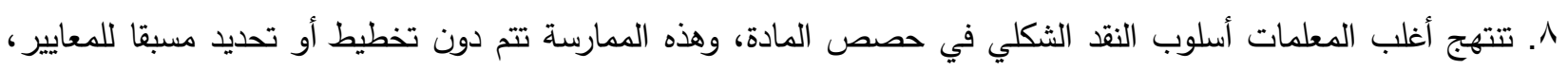
وبالتالي بدون أي توقع للنتائج.

9 9. لا تقوم المعلمات بالتتويع بين أساليب النقد الفني المتبعة خلال حصص التصائ التربية الفنية.

تُبرز هذه النتائج عدم تطوير التعليم والمناهج التعليمية في المملكة العربية السعودية واستفادتها من الدراسات المعدة في مجال

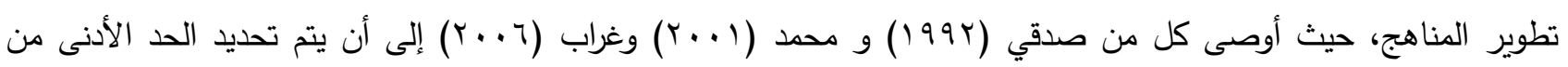

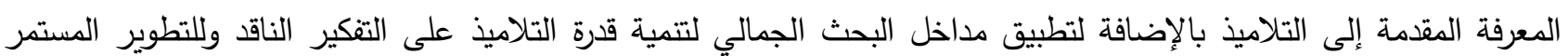
لمهارة التلاميذ النقدية. ومن خلال مقارنة الاستجابات في بطاقة الملاحظة مع الاستجابات في الاستبيان توصل الباحثان إلى عدم صدق المعلمات في بعض عبارات الاستبيان عند مقارنتها ببطاقة الملاحظة. 
• ضرورة إعادة صياغة الخطط المعتمدة من إدارة التربية والتعليم، وإدراج النقد الفني ضمن أهدافها ووسائلها.

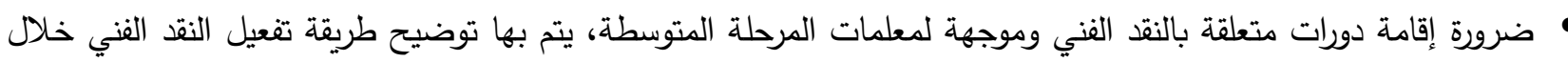
حصص المادة.

تزويد المعلمات ببعض قوائم المراجع الخاصة بالنقد الفني من أجل زيادة معلوماتهن عن النقد الفني. عقد الدورات التدريبية للمعلمات على رأس الخدمة وتطويرهن وتدريبهن على الطرق الحديثة للتدريس وطرق تفعيلها في مادة التربية الفنية. • إعادة النظر في طرق الإعلان للدورات التدريبية وطرق التسجيل بالإضافة إلى مواعيد هذه الدورات. • • ضرورة إعادة النظر في برامج إعداد المعلم في الكليات والجامعات.

• ضرورة أن تتضمن برامج إعداد معلمات التربية الفنية بعض المقررات المتعلقة بتفعيل النقد الفني في مراحل التعليم العام. • التأكيد على زيارة التلميذات للمعارض التشكيلية والمتاحف بصحبة معلمة التربية الفنية، والتدرب على نقد الأعمال الفنية

المعروضة فيها. عقد دورات تثثيفية بأهمية الاستبيانات البحثية وطرق تعبئتها بواقعية وشفافية.

\section{مقترحات البحث:}

ا. إقامة دراسة تجريبية لتفعيل النقد الفني خلال حصص المادة، والكثف عن العلاقة بين تفعيل النقد الفني في حصص المادة

$$
\text { والقدرة على إثراء لغة التلاميذ في المفردات الفنية. }
$$

r r بحث مماثل لهذا البحث في مناطق مختلفة من المملكة العربية السعودية.

\section{المراجع:}

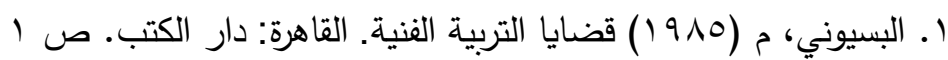

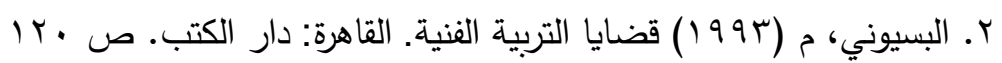

r. جسومه، ل (99 (1) تحليل مضمون الكتاب المقرر في التربية الفنية على تلميذات التعلم الابتدائي والمتوسط بالمملكة العربية السعودية وعلاقته باتجاهات التربية الفنية المعاصرة. رسالة ماجستير غير منشورة. مكة المكرمة: جامعة أم القرى.

$$
\text { ص }
$$

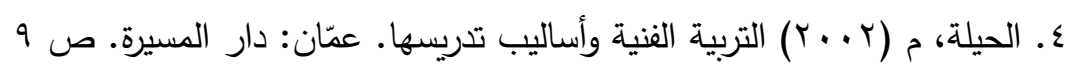

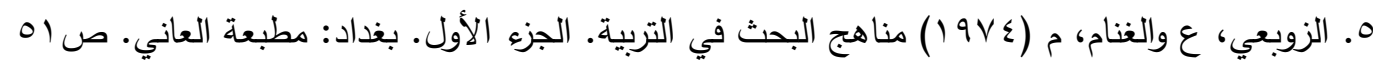

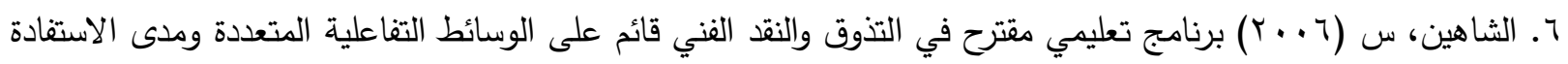

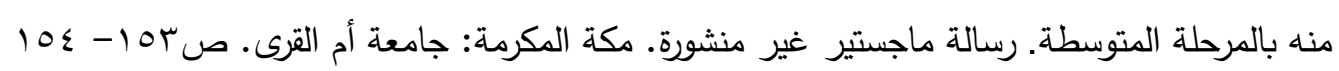

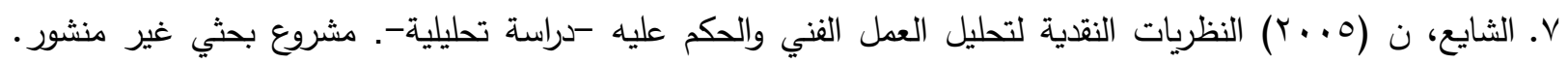

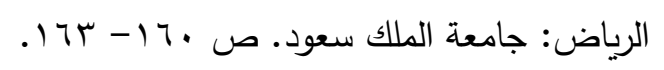

^. الثربتي، إ (999 (19) تطوير منهج التربية الفنية للمرحلة الإعدادية في دولة البحرين في ضوء نموذج المفاهيم المعرفية.

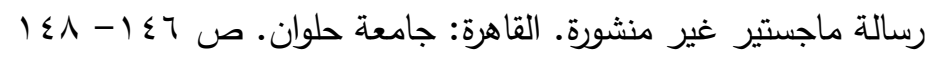

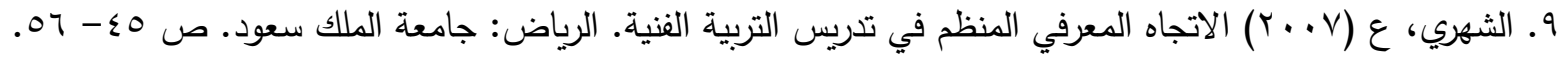

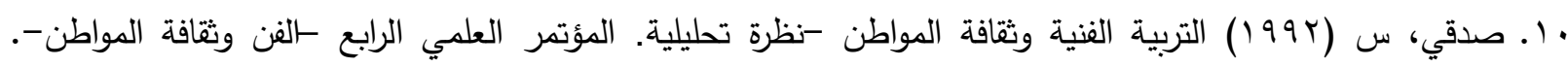

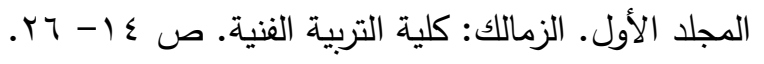




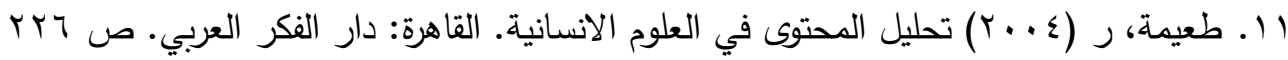

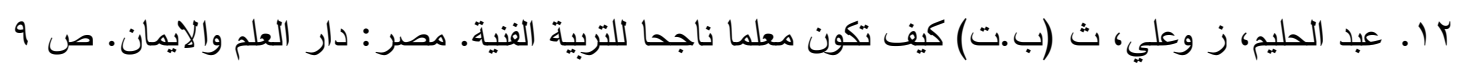

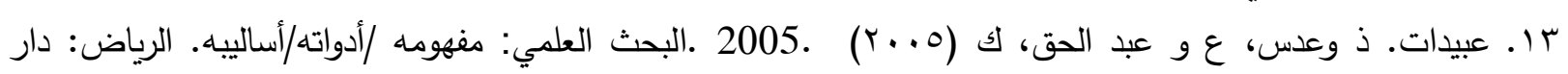

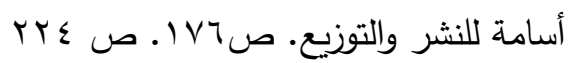

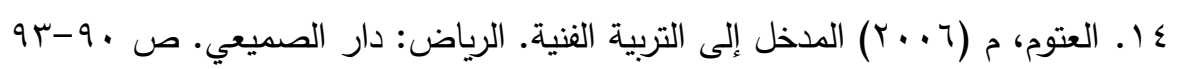

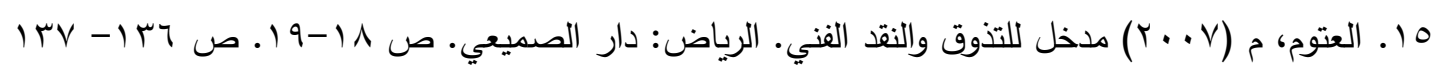

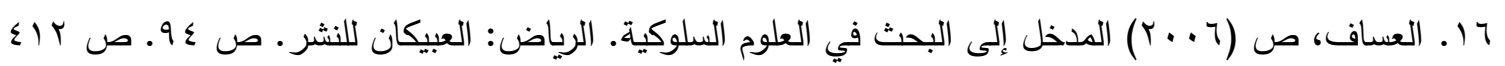

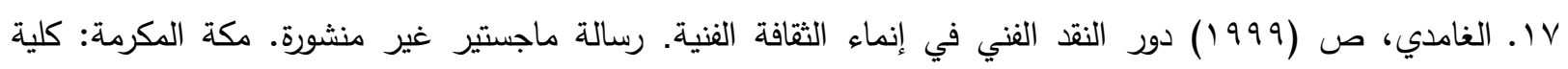

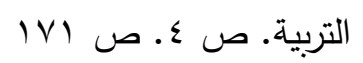

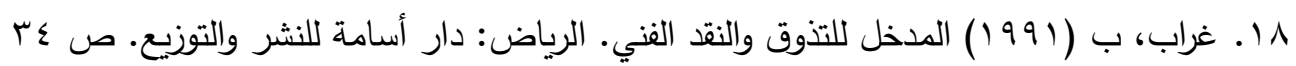

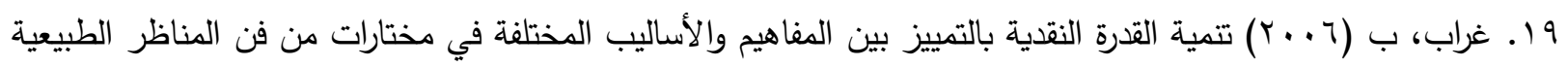

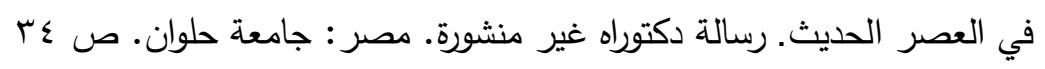

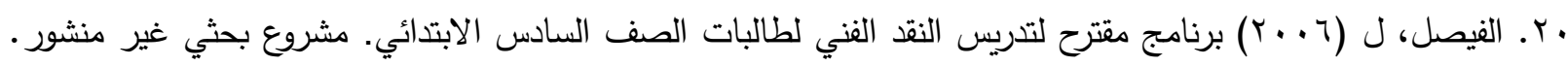

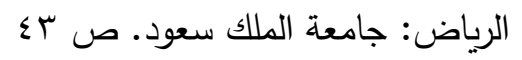

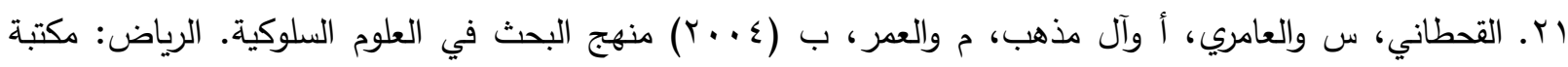

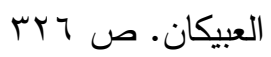

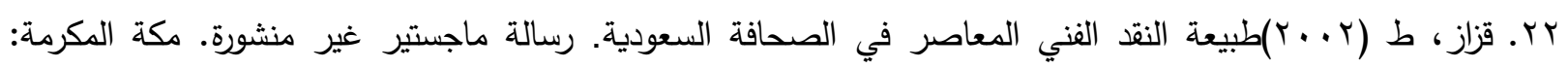

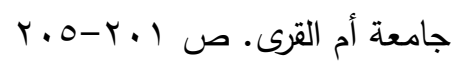

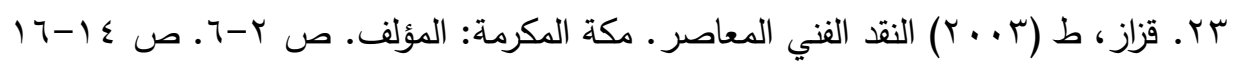

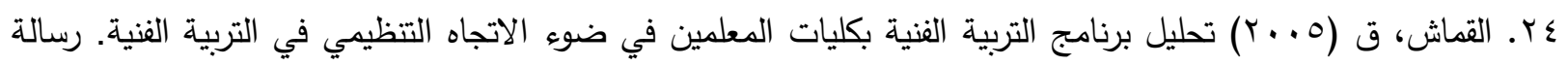

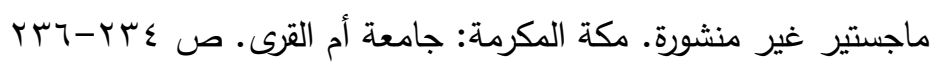

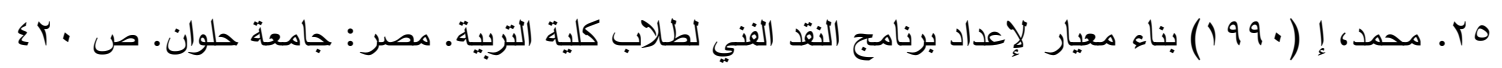

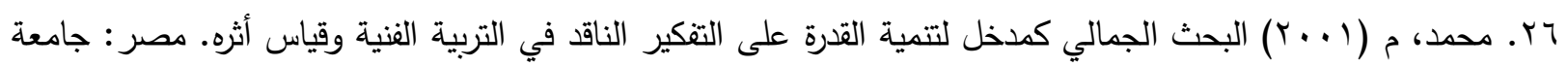
حلوان. ص ع

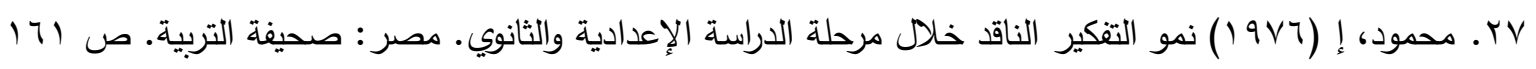

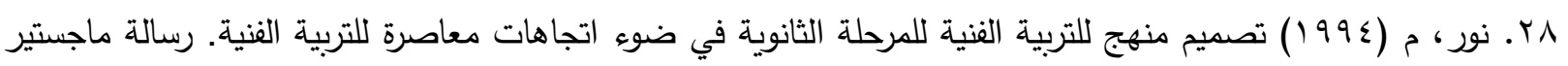

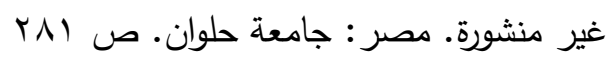

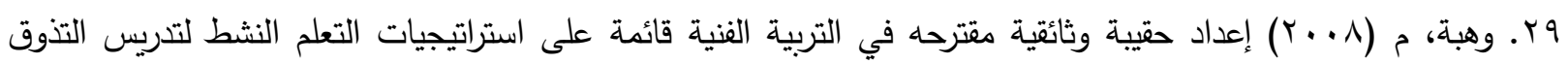

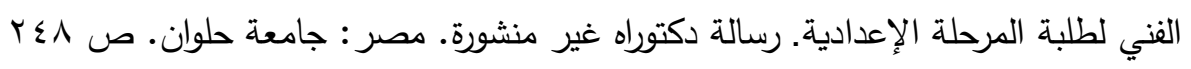




\title{
Evaluation of Technical Criticism Skills of Art Education Teachers and Teaching them in The Intermediate Schools in Riyadh
}

\author{
Ghadah Abdulrahman Aldossary \\ Curriculum and Teaching Methods Lecturer in Art education- King Saud University \\ ghaldossari@ksu.edu.sa
}

Abdullah Dafer Alshihry

Curriculum and Teaching Methods Professor- King Saud University

adshehri@ksu.edu.sa

\begin{abstract}
:
The main goal of this research is to investigate the reality of activation of art criticism in the intermediate schools, in addition to measuring the information of art teachers on the meaning and methods of art criticism and its relevance to students through a questionnaire that was designed by the researchers to be applied to a sample survey of two hundred and twenty-eight teachers, in addition to a note card to be applied on quarter of the sample.
\end{abstract}

\section{Important results:}

- $10 \%$ of the teachers had very poor knowledge on Art Criticism, and 17.2\% who had high knowledge on Art Criticism.

- $52.1 \%$ of teachers possess little information about the meaning of art criticism, compared to $31.5 \%$ who possess little information about the methods of art criticism, and 1.4\% possess little information about the importance of art criticism to the student.

- Teachers do not include art criticism within the objectives of the plan in their monthly or annual planning reports. On the Other hand, $14.5 \%$ of them include art criticism in their daily planning.

- $48.7 \%$ of the teachers apply art criticism through out all classes, and $12.7 \%$ apply art criticism from time to time without planning the process and without any explaining the methods of art criticism to the students.

\section{Important Recommendations and Suggestions:}

- It is Important to re-formulate the plans approved by the Department of Education, and to include art criticism within the objectives and means.

- It is important to develop courses directed to intermediate school teachers, related to art criticism, in which the activation of art criticism though out classes is clarified.

It is essential to Provide art teachers with some references on art criticism in order to increase their knowledge of art criticism.

Keywords: Technical Criticism, Art Education. 